\title{
AE Succinimide, an Analogue of Methyllycaconitine, When Bound Generates a Nonconducting Conformation of the $\alpha 4 \beta 2$ Nicotinic Acetylcholine Receptor
}

Taima Qudah, Gracia X. Quek, Dinesh Indurthi, Nasiara Karim, Jill I. Halliday, Nathan Absalom, Malcolm D. McLeod, and Mary Chebib*

Cite This: ACS Chem. Neurosci. 2020, 11, 344-355

ABSTRACT: Nicotinic acetylcholine (nACh) receptors are pentameric ligand-gated ion channels that mediate fast synaptic transmission. The $\alpha 4 \beta 2 \mathrm{nACh}$ receptor is highly expressed in the brain and exists in two functional stoichiometries: the $(\alpha 4)_{2}(\beta 2)_{3}$ and $(\alpha 4)_{3}(\beta 2)_{2}$ that differ by an ACh-binding site at the $\alpha 4-\alpha 4$ interface of $(\alpha 4)_{3}(\beta 2)_{2}$ receptors. Methyllycaconitine (MLA) is an nACh receptor antagonist, and while potent at both $\alpha 7$ and $\alpha 4 \beta 2$ $\mathrm{nACh}$ receptors, it has a higher selectivity for the $\alpha 7 \mathrm{nACh}$ receptor. The anthranilate-succinimide ester side-chain is impor-

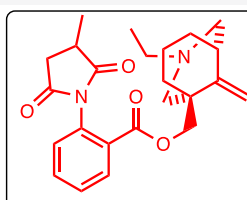

AE succinimide $\left(\alpha 4^{13^{\prime} \mathrm{C}}\right)_{3}(\beta 2)_{2} \mathrm{nAChR}$ inhibitor

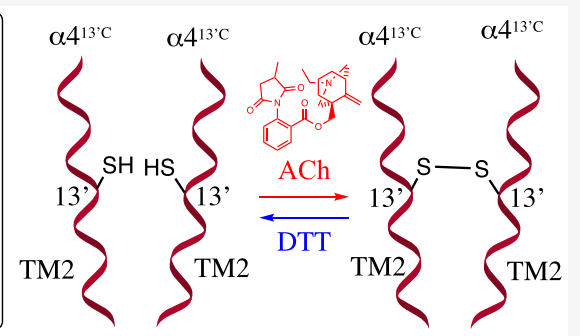
tant for its activity and selectivity. Here we identify a simplified MLA analogue that contains only the A and E ring skeleton of MLA, AE succinimide, that binds close to the channel lumen to display insurmountable inhibition at $\alpha 4 \beta 2 \mathrm{nACh}$ receptors. Although inhibition by AE succinimide was found to be voltagedependent indicating a possible pore channel blocker, substituted-cysteine accessibility experiments indicated it did not bind between $2^{\prime}-16^{\prime}$ region of the channel pore. Instead, we found that upon binding and in the presence of ACh, there is a conformational change to the channel membrane that was identified when the compound was assessed against $\left(\alpha 4 \mathrm{~V} 13^{\prime} \mathrm{C}\right) \beta 2 \mathrm{nACh}$ receptors. It was found that in the 3:2 stoichiometry the two adjacent $\alpha 4$ subunits containing $13^{\prime}$ cysteine mutations formed a disulfide bond and occluded ion conductance. This was reversed by treatment with the reducing agent, dithiothreitol. Thus, AE succinimide has a different mechanism of inhibition to both MLA and other AE analogues, such as AE bicyclic alcohol, in that upon binding to an as yet unidentified site, $\mathrm{AE}$ succinimide in the presence of $\mathrm{ACh}$ induces a conformational change to the channel that generates a ligand-bound closed state.

KEYWORDS: Ligand-gated ion channel, nicotinic acetylcholine receptor, noncompetitive antagonist, substituted cysteine accessibility method, methyllycaconitine

\section{INTRODUCTION}

Neuronal nicotinic acetylcholine (nACh) receptors are ligandgated ion channels (LGIC) that mediate fast synaptic transmission between nerve cells. These receptors are widely distributed in both the peripheral and central nervous systems and have been implicated in different physiological and neurological conditions including Alzheimer's disease, nicotine addiction, pain, epilepsy, and schizophrenia. ${ }^{1,2}$

Nicotinic acetylcholine receptors are assembled from five subunits that are arranged pseudosymmetrically around a central cation-conducting pore. Each subunit is composed of a large extracellular $\mathrm{N}$-terminal region, four transmembrane domains (TM1-TM4), two short loops between TM1 and TM2 and between TM2 and TM3, a large intracellular loop between TM3 and TM4, and a short extracellular carboxy terminal. The channel pore is lined by the $\alpha$-helical TM2 domain, where cations passively pass through the open receptor. ${ }^{3,4}$ Binding of $\mathrm{ACh}$ to $\mathrm{nACh}$ receptors at the interface of two subunits in the extracellular domain results in a series of conformational changes that lead to the rotation of the TM2 domain to open the channel.

To date, 12 different $\mathrm{nACh}$ receptor subunits $(\alpha 2-\alpha 10$ and $\beta 2-\beta 4)$ have been identified and cloned from the mammalian brain. Different arrangements of these subunits lead to a wide variety of individual receptor subtypes, each with distinct pharmacological and physiological properties. ${ }^{1,2}$ Therefore, there is great interest in developing selective neuronal $\mathrm{nACh}$ receptor ligands as research tools and therapeutic agents in

Received: September 29, 2019

Accepted: January 3, 2020

Published: January 3, 2020 
order to understand the role each receptor subtype plays in brain function.

The TM2 domain incorporates the binding site for many noncompetitive antagonists, including tetracaine, carbamazepine, and barbiturates, as well as anesthetics such as phencylidine and ketamine (for a review, see ref 5). Many noncompetitive antagonists inhibit $\mathrm{nACh}$ receptors by binding within the channel lumen, occluding it and physically blocking ion permeability. Some channel blockers such as quinacrine appear to bind only when the channel pore opens, requiring an agonist such as $\mathrm{ACh}$ to first bind at orthosteric sites to modulate the accessibility of channel blockers to the pore. ${ }^{6}$ Other noncompetitive antagonists block both the open and closed states of the receptor. ${ }^{5,7,8}$

Of the many reported receptor subtypes, the homomeric $\alpha 7$ and heteromeric $\alpha 4 \beta 2 \mathrm{nACh}$ receptors are the most widely expressed in the brain. ${ }^{1}$ The $\alpha 4 \beta 2 \mathrm{nACh}$ receptor exists in two pharmacologically distinct receptor stoichiometries, $(\alpha 4)_{2}(\beta 2)_{3}$ and $(\alpha 4)_{3}(\beta 2)_{2}$. The $(\alpha 4)_{2}(\beta 2)_{3}$ nACh receptor has high sensitivity to ACh, whereas the $(\alpha 4)_{3}(\beta 2)_{2} \mathrm{nACh}$ receptor has lower sensitivity. The difference in sensitivities to ACh between the two stoichiometries is due to the presence of a third low-affinity ACh-binding site located at the $\alpha 4-\alpha 4$ interface in the $(\alpha 4)_{3}(\beta 2)_{2}$ stoichiometry, and this site is in addition to the two common $\alpha 4-\beta 2$ binding sites that occur in both stoichiometries. ${ }^{9-14}$

Methyllycaconitine (MLA) (Figure 1) is an $\mathrm{nACh}$ receptor antagonist, and while potent at both $\alpha 7$ and $\alpha 4 \beta 2 \mathrm{nACh}$
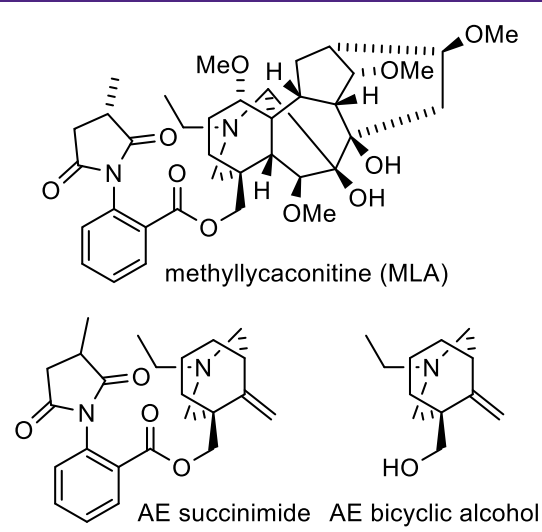

Figure 1. Chemical structures for methyllycaconitine (MLA), AE succinimide, and $\mathrm{AE}$ bicyclic alcohol. receptors, it is selective for $\alpha 7 \mathrm{nACh}$ receptors (picomolar versus nanomolar affinity, respectively). ${ }^{15,16}$ Despite this difference in potency, we pursued developing a series of simpler MLA analogues that had the A and E ring skeleton of MLA, including $A E$ succinimide and $A E$ bicyclic alcohol (Figure 1), that incorporated either the anthranilatesuccinimide (2-[3-methyl-2,5-dioxopyrrolidin-1-yl]benzoate) or alcohol side-chains, ${ }^{17,18}$ respectively, in order to identify compounds that were more potent for $\alpha 4 \beta 2 \mathrm{nACh}$ receptors. Structure-activity studies on MLA analogues had previously demonstrated that the anthranilate-succinimide moiety is a key structural determinant for competitive receptor binding at $\alpha 7$ receptors, possibly anchoring the compound to the orthostericbinding site. However, at $\alpha 4 \beta 2 \mathrm{nACh}$ receptors, both MLA and anthranilate-succinimide analogues displayed either competitive or insurmountable inhibition depending on whether the antagonist was preincubated or not. ${ }^{18}$ In contrast, analogues of MLA that lacked the anthranilate-succinimide side chain, such as AE bicyclic alcohol, bound solely to the TM2 domain at the $13^{\prime}$ position ${ }^{18,19}$ of $\alpha 4 \beta 2$ nACh receptors as a noncompetitive channel blocker.

In the work presented here, we determined that in contrast to AE bicyclic alcohol, AE succinimide does not directly bind to the $13^{\prime}$ site of the TM2 domain but binds to several sites including the orthosteric site and a site close to or within the channel lumen to inhibit $\alpha 4 \beta 2 \mathrm{nACh}$ receptors. By mutating the $13^{\prime}$ site of the $\alpha 4$ subunit TM2 domain to a cysteine, we show that $\mathrm{AE}$ succinimide in the presence of $\mathrm{ACh}$ induces a conformational change in the $\alpha 4$ subunit that enables adjacent cysteines within the channel pore to form a disulfide bond occluding ion conductance. This can be reversed with DTT. Thus, AE succinimide has a different mechanism of inhibition to both MLA and AE bicyclic alcohol $\alpha 4 \beta 2 \mathrm{nACh}$ receptor.

\section{RESULTS AND DISCUSSION}

AE Succinimide Incubation Dictates Surmountable and Insurmountable Inhibition of $\mathrm{ACh}$ at $\alpha 4 \beta 2$ Receptors. In this study we evaluated the effect of $\mathrm{AE}$ succinimide against rat $\alpha 4 \beta 2 \mathrm{nACh}$ receptor stoichiometries. The assembly of different stoichiometries of $\alpha 4 \beta 2 \mathrm{nACh}$ receptors in Xenopus laevis oocytes can be directed by injecting oocytes with different ratios of $\alpha 4$ to $\beta 2 \mathrm{mRNA}$. Acetylcholine differs in potency at each receptor because it can bind to two distinct interfaces within the extracellular domain; the $\alpha 4-\beta 2$ and $\alpha 4-\alpha 4$ interfaces. Thus, to express the two stoichiometries, we used an excess amount of $\beta 2$ subunit mRNA in either

Table 1. Pharmacological Data for ACh Alone and in the Presence of AE Succinimide with and without a 3 min Preincubation at $\alpha 4 \beta 2(1: 10)$ and $\alpha 4 \beta 2(1: 1)$ nACh Receptors

\begin{tabular}{|c|c|c|c|c|c|c|}
\hline receptor ratio & application & $\begin{array}{l}\text { incubation } \\
\quad(\mathrm{min})\end{array}$ & $\mathrm{EC}_{50}(\mu \mathrm{M})^{b}(95 \% \mathrm{CI})^{c, h}$ & $I_{\mathrm{Max}}^{d}(95 \% \mathrm{CI})^{c, i}$ & $n_{\mathrm{H}}^{e}(95 \% \mathrm{CI})^{c}$ & $n$ \\
\hline$\alpha 4 \beta 2(1: 10)^{a}$ & ACh alone & none & $1.7(1.2-2.4)$ & $1.04(0.98-1.11)$ & $0.88(0.6-1.2)$ & 4 \\
\hline$\alpha 4 \beta 2(1: 1)$ & ACh alone & none & $136(99.5-186.5)$ & $1.16(1.06-1.26)$ & $0.98(0.72-1.23)$ & 11 \\
\hline$\alpha 4 \beta 2(1: 1)$ & $\mathrm{ACh}+30 \mu \mathrm{M} \mathrm{AE}$ succinimide & none & $2.6(0.13-52.2) 912(506-1644) * * *$ & $1.07(0.96-1.17)$ & n.d. ${ }^{g}$ & 6 \\
\hline$\alpha 4 \beta 2(1: 1)$ & $\mathrm{ACh}+3 \mu \mathrm{M}$ AE succinimide & 3 & $446(291.1-683.7) * * *$ & $0.97(0.90-1.17)$ & $1.09(0.90-1.51)$ & 5 \\
\hline$\alpha 4 \beta 2(1: 1)$ & $\mathrm{ACh}+30 \mu \mathrm{M} \mathrm{AE}$ succinimide ${ }^{f}$ & 3 & $561(149.1-2105) * * *$ & $0.5(0.30-0.70) * *$ & $0.92(-0.09$ to 1.90$)$ & 5 \\
\hline
\end{tabular}

${ }^{a}$ Data taken from ref $20 .{ }^{b} \mathrm{EC}_{50}$ is the effective concentration that activates $50 \%$ of the receptor. ${ }^{c} 95 \%$ confidence intervals $(\mathrm{CI}) .{ }^{d} I_{\mathrm{Max}}$ is the maximum current produced by ACh alone or ACh in the presence of an antagonist. ${ }^{e} n_{\mathrm{H}}$ is the Hill slope or Hill coefficient. ${ }^{f}$ Data taken from ref 19.

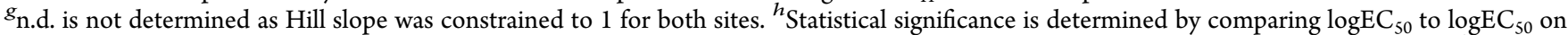
wild-type by applying Tukey's multiple comparisons test one way ANOVA $\left({ }^{*} p<0.05,{ }^{*} p<0.01, * * * p<0.001, * * * * p<0.0001\right){ }^{i}$ Statistical significance is determined by comparing $I_{\text {Max }}$ to $I_{\text {Max }}$ on wild-type by applying Tukey's multiple comparisons test one way ANOVA (* $p<0.05$, $* * p$ $<0.01, * * * p<0.001, * * * * p<0.0001)$. 


\section{A Effect of $A E$ Succinimide incubation on $(\alpha 4)_{3}(\beta 2)_{2}$ receptors}

\section{B ACh concentration response curve without incubation at $(\alpha 4)_{3}(\beta 2)_{2}$ receptors}
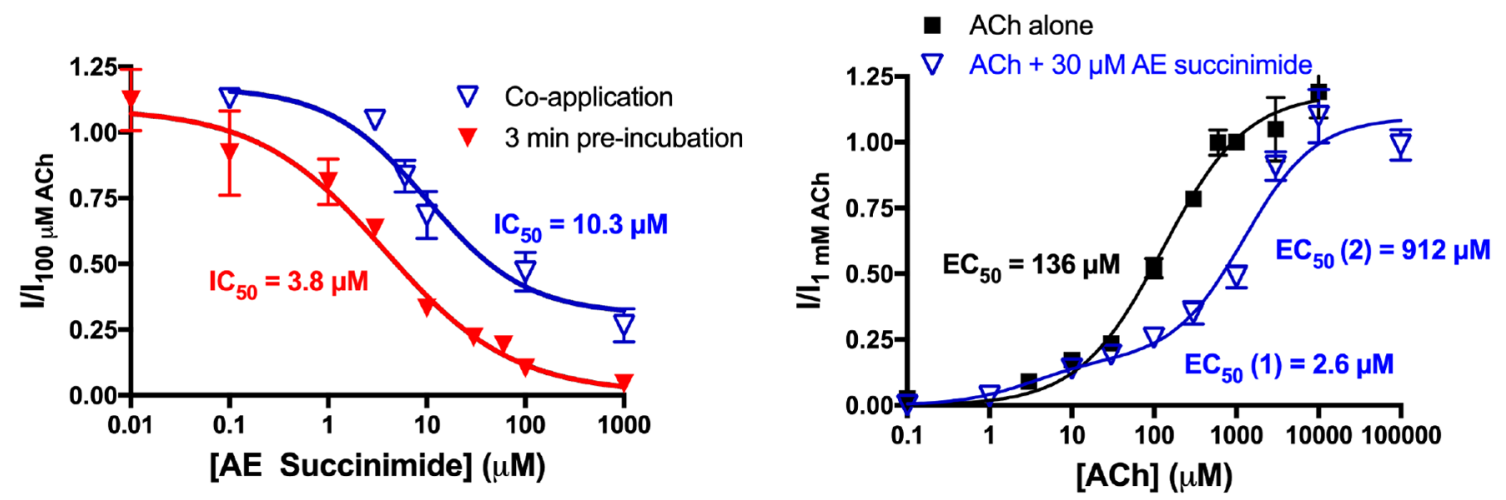

\section{ACh concentration response curves with incubation at $(\alpha 4)_{3}(\beta 2)_{2}$ receptors}

\section{Effect of AE Succinimide incubation on $(\alpha 4)_{2}(\beta 2)_{3}$ receptors}
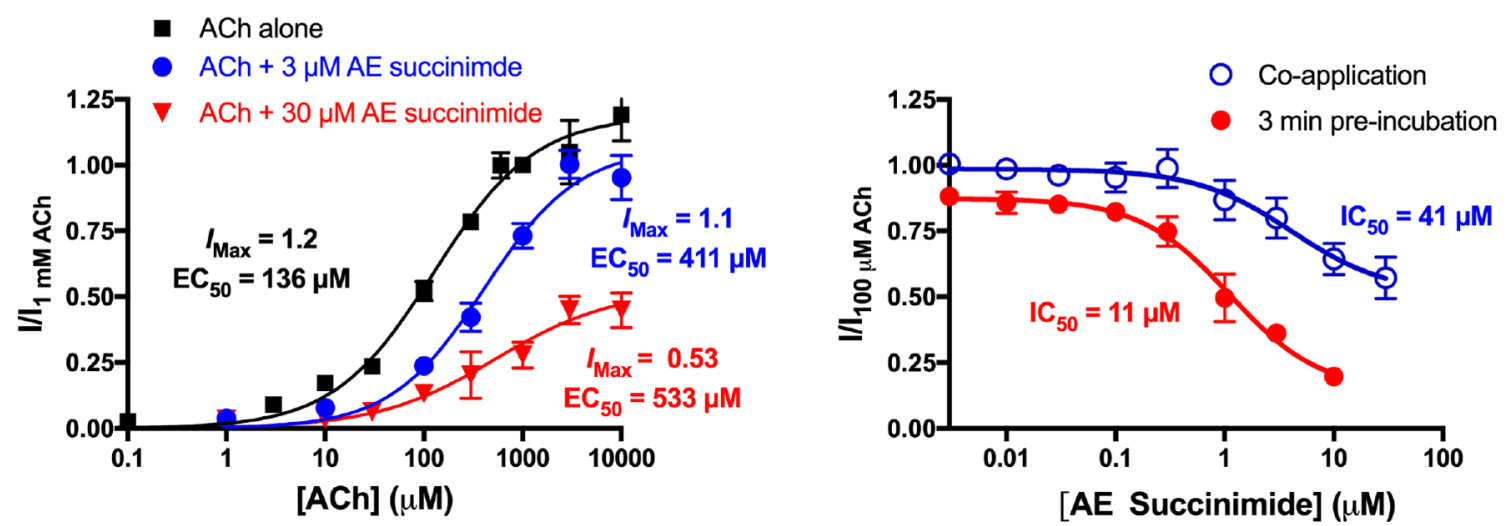

Figure 2. (A) Inhibitory concentration-response curves for AE succinimide in the presence of $100 \mu \mathrm{M}$ ACh at rat $(\alpha 4)_{3}(\beta 2)_{2} \mathrm{nACh}$ receptors obtained from injecting a 1:1 mRNA ratio $\alpha 4: \beta 2$ in Xenopus oocytes. AE succinimide was either preincubated for 3 min before coapplying with 100 $\mu \mathrm{M}$ ACh (red $\boldsymbol{\nabla}$ ) or coapplied with $100 \mu \mathrm{M}$ ACh without incubation (blue $\nabla$ ). Data were normalized to $100 \mu \mathrm{M}$ ACh alone and are presented as mean \pm SEM ( $n=5-8$ oocytes; $>2$ batches of oocytes). (B) Concentration-response curves for ACh alone $(\boldsymbol{\square})$ or ACh in the presence of $30 \mu \mathrm{M}$ $\mathrm{AE}$ succinimide without preincubation (blue $\nabla$ ). (C) Concentration-response curves for ACh alone $(\boldsymbol{\square})$ and ACh with a 3 min preincubation with $3 \mu \mathrm{M}$ AE succinimide (blue - ) or with $30 \mu \mathrm{M}$ AE succinimide (red $\boldsymbol{\nabla})$. Data for panels B and C were obtained from rat $(\alpha 4)_{3}(\beta 2)_{2} \mathrm{nACh}$ receptors injected with a 1:1 mRNA ratio $\alpha 4: \beta 2$ in Xenopus oocytes, normalized to $1 \mathrm{mM} \mathrm{ACh}$, and presented as mean \pm SEM $(n=5-11$ oocytes; $>2$ batches of oocytes). (D) Inhibitory concentration-response curves for AE succinimide in the presence of $100 \mu \mathrm{MACh}$ at rat $(\alpha 4)_{2}(\beta 2)_{3} \mathrm{nACh}$ receptors obtained from injecting a 1:10 mRNA ratio $\alpha 4: \beta 2$ in Xenopus oocytes. AE succinimide was either preincubated for 3 min before coapplying with $100 \mu \mathrm{M}$ ACh (red $\bullet$ ) or coapplied with $100 \mu \mathrm{M}$ ACh without incubation (blue $\mathrm{O}$ ). Data were normalized to $100 \mu \mathrm{M}$ ACh and are presented as mean \pm SEM ( $n=3$ oocytes; $>2$ batches of oocytes).

1:4 or $1: 10 \alpha 4: \beta 2$ ratio to obtain the $2: 3$ stoichiometry and either 1:1 or excess amount of $\alpha 4$ mRNA in 10:1 $\alpha 4: \beta 2$ ratio to obtain the $3: 2$ stoichiometry. Acetylcholine concentrationresponse curves were obtained for both stoichiometries using two-electrode voltage clamp (2-EVC) methods. The $\mathrm{EC}_{50}$ values for ACh $(1.7 \mu \mathrm{M}$ and $136 \mu \mathrm{M}$, Table 1$)$ were similar to previously published values from experiments using human $\alpha 4 \beta 2 \mathrm{nACh}$ receptors of 1.6 and $83 \mu \mathrm{M}$ for the $(\alpha 4)_{2}(\beta 2)_{3}$ and $(\alpha 4)_{3}(\beta 2)_{2}$ stoichiometries, respectively. ${ }^{13}$

Previously we demonstrated that the mode of antagonism by MLA changes from surmountable to insurmountable depending on whether MLA was preincubated or not when evaluated against $\mathrm{ACh} .{ }^{20}$ Given that changes in the mode of antagonism are observed for MLA and other MLA analogues, ${ }^{19,20}$ we assessed $\mathrm{AE}$ succinimide against inhibiting $\mathrm{ACh}$ at $(\alpha 4)_{3}(\beta 2)_{2}$ receptors with and without a 3 min preincubation step (Figure 2A), a time previously determined using both MLA and AE bicyclic alcohol that maximally inhibited the $\mathrm{ACh}$ response. ${ }^{19,20}$ Using a concentration of ACh close to the $\mathrm{EC}_{50}$ value $(100 \mu \mathrm{M})$ for the 3:2 stoichiometry, we assessed the inhibitory effect of $\mathrm{AE}$ succinimide with and without preincubation (Figure 2A). At this concentration, the $\alpha 4-\beta 2$ sites will be fully occupied along with partial occupancy of the $\alpha 4-\alpha 4$ binding sites.

The $\mathrm{IC}_{50}$ value of $\mathrm{AE}$ succinimide against $\mathrm{ACh}$ was statistically lower after the $3 \mathrm{~min}$ preincubation $\left(\mathrm{IC}_{50}=3.8\right.$ $\mu \mathrm{M})$ than without $\left(\mathrm{IC}_{50}=10.3 \mu \mathrm{M}\right.$; Student $t$ test on $\log \mathrm{IC}_{50}$, $p<0.05)$. At $1 \mathrm{mM} \mathrm{AE}$ succinimide, the $\mathrm{ACh}$ response was completely inhibited when preincubated but had a $25 \pm 5 \%$ residual response when not preincubated. Hence, a preincu- 


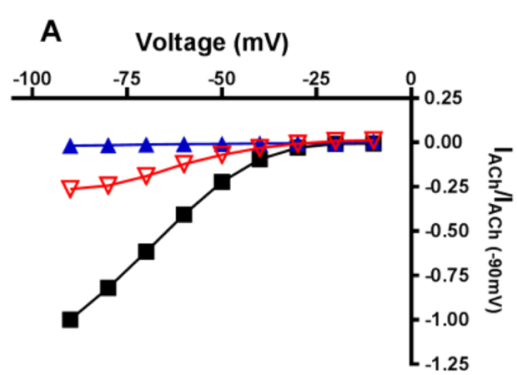

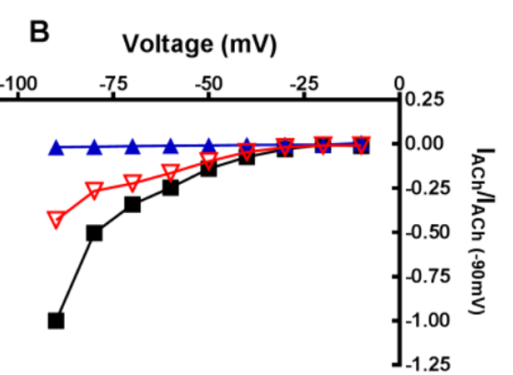

C

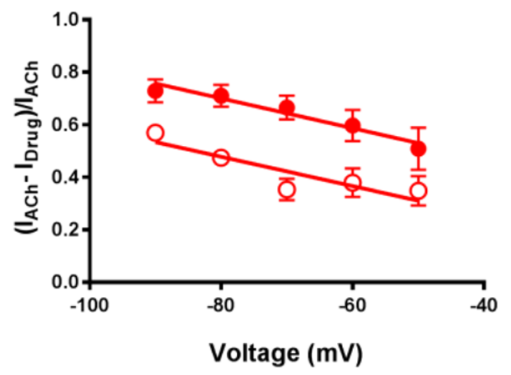

Figure 3. Voltage-dependent inhibition of ACh-induced currents in the presence of AE succinimide at (A) rat $(\alpha 4)_{3}(\beta 2)_{2}$ and $(\mathrm{B})$ rat $(\alpha 4)_{2}(\beta 2)_{3}$ nACh receptors obtained from injecting a 1:1 or 1:4 mRNA ratio $\alpha 4: \beta 2$ in Xenopus oocytes, respectively. Current-voltage (I-V) curves for both

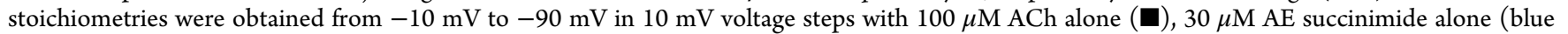
$\boldsymbol{\Delta})$, and $30 \mu \mathrm{M} \mathrm{AE}$ succinimide preincubated for $3 \mathrm{~min}$ before coapplication of $100 \mu \mathrm{M}$ ACh (red $\nabla)$. Data were normalized to the current generated by $100 \mu \mathrm{M} \mathrm{ACh}$ at $-90 \mathrm{mV}$. (C) The fraction of the ACh response that is inhibited by $30 \mu \mathrm{M} \mathrm{AE}$ succinimide in $10 \mathrm{mV}$ steps at rat $(\alpha 4)_{3}(\beta 2)_{2}$ (red $\bullet$ ) and rat $(\alpha 4)_{2}(\beta 2)_{3}$ (red $\left.O\right)$ at different holding potentials. Current-voltage relationships were obtained from least-squares linear regression fits. Points are presented as mean \pm SEM $(n=4$ oocytes; $>2$ batches of oocytes).

bation of 3 min results in a $2-3$ fold increase in the potency of $\mathrm{AE}$ succinimide at the $(\alpha 4)_{3}(\beta 2)_{2}$ receptor, and this observation is similar to what was previously reported with MLA and other AE analogues. ${ }^{19,20}$

To determine the effect of incubating AE succinimide on the mode of antagonism at $(\alpha 4)_{3}(\beta 2)_{2}$ receptors, we performed ACh-response curves in the presence of an approximate $\mathrm{IC}_{50}$ concentration of $\mathrm{AE}$ succinimide without and with preincubation (panels $\mathrm{B}$ and $\mathrm{C}$ of Figure 2, respectively). The concentration of $\mathrm{AE}$ succinimide was $30 \mu \mathrm{M}$ when used without preincubation and $3 \mu \mathrm{M}$ and $30 \mu \mathrm{M}$ AE succinimide when used with a 3 min preincubation (panels $B$ and $C$ of Figure 2, respectively; Table 1). When AE succinimide was not preincubated, the concentration response curve for $\mathrm{ACh}$ in the presence of $\mathrm{AE}$ succinimide $(30 \mu \mathrm{M})$ preferred a biphasic over a monophasic response curve (F-test, $p=0.008$; $\mathrm{dF}$ (7.86, 1, $38)$ ). Biphasic concentration response curves are commonly observed with $\mathrm{ACh}$ on heteromeric nACh receptors such as $(\alpha 4)_{3}(\beta 2)_{2}$ because there are two distinct binding sites for ACh located at the $\alpha 4-\beta 2$ and $\alpha 4-\alpha 4$ interfaces representing the high- and low-affinity sites, respectively. ${ }^{9-14}$ The ACh response attributed to the $\alpha 4-\beta 2$ interface constitutes approximately $25 \%$ of the total response and appeared not to be affected by $30 \mu \mathrm{M}$ AE succinimide when not preincubated. The $\mathrm{EC}_{50}$ for $\mathrm{ACh}$ for this component was $2.6 \mu \mathrm{M}\left(\operatorname{logEC} \mathrm{C}_{50}=\right.$ $0.42 \pm 1.3$ ). In contrast, there was a rightward shift in the ACh concentration response curve attributed to the low-affinity ACh binding $\alpha 4-\alpha 4$ interface, resulting in an $\sim 8$-fold increase in the $\mathrm{EC}_{50}$ value for $\mathrm{ACh}$ without a change in the $I_{\mathrm{Max}}\left(\mathrm{EC}_{50}=\right.$ $912 \mu \mathrm{M} ; \log \mathrm{EC}_{50}=2.96 \pm 0.26$; one-way ANOVA with Tukey's posthoc test on $\log \mathrm{EC}_{50}, p<0.0001$; Figure $2 \mathrm{~B}$ and Table 1).

In contrast, when $3 \mu \mathrm{M}$ AE succinimide was preincubated and subsequently coapplied with $\mathrm{ACh}$, the $\mathrm{ACh}$ response curve shifted to the right and the $I_{\mathrm{Max}}$ was not significantly affected $\left(\mathrm{EC}_{50}=411 \mu \mathrm{M} ; \log \mathrm{EC}_{50}=2.61 \pm 0.11\right.$; Table 1 ; one-way ANOVA with Tukey's posthoc test on $\log \mathrm{EC}_{50}, p<0.001$; Figure 2C). However, with $30 \mu \mathrm{M} A E$ succinimide there was no further change to the $\mathrm{EC}_{50}\left(\mathrm{EC}_{50}=533 \mu \mathrm{M} ; \log \mathrm{EC}_{50}=\right.$ $2.73 \pm 0.37 ; p>0.05)$ but the $I_{\mathrm{Max}}$ was significantly reduced by 2-3-fold compared to ACh alone (0.53 c.f 1.2; one-way ANOVA with Tukey's posthoc test on $I_{\text {Max }} p<0.01$ ). All curves preferred a monophasic model compared to biphasic model (AE succinimide $(3 \mu \mathrm{M}), \mathrm{p}=0.51$ and $30 \mu \mathrm{M} \mathrm{p}=$ 0.86). Taken together the data indicate that $\mathrm{AE}$ succinimide displays insurmountable antagonism at these concentrations. The increase in inhibition of the $I_{\mathrm{Max}}$ during preincubation of $\mathrm{AE}$ succinimide in the closed state, rather than the open state, suggests that the inhibitor is binding to a site distinct from ACh with slower kinetics in the closed, or both open and closed states.

We then assessed AE succinimide at the $(\alpha 4)_{2}(\beta 2)_{3}$ receptor with and without a 3 min preincubation. For this experiment we used $100 \mu \mathrm{M} \mathrm{ACh}$, a concentration of ACh close to the $I_{\text {Max }}$, because this concentration would saturate the $\alpha 4-\beta 2$ sites as it had done so when we examined $(\alpha 4)_{3}(\beta 2)_{2} \mathrm{nACh}$ receptors. Inhibitory response curves for $\mathrm{ACh}$ indicated that $\mathrm{AE}$ succinimide was more potent at inhibiting ACh-induced currents elicited from $(\alpha 4)_{2}(\beta 2)_{3}$ receptors when preincubated $\left(\mathrm{IC}_{50}=11.0 \mu \mathrm{M} ; \operatorname{logIC} \mathrm{I}_{50}=1.05 \pm 0.15\right)$ compared to no incubation $\left(\mathrm{IC}_{50}=41.4 \mu \mathrm{M} ; \log \mathrm{IC}_{50}=1.617 \pm 0.38\right.$; Student $t$ test on $\log \mathrm{IC}_{50}, p<0.05$; Figure 2D).

AE Succinimide Displays Voltage-Dependent Blockade at $\alpha 4 \beta 2$ Receptors. It is well-documented that insurmountable antagonism is achieved if a compound binds to the TM2 domain and blocks the channel pore. ${ }^{21}$ Indeed, a variety of MLA analogues have been reported to be channel blockers of $\alpha 4 \beta 2 \mathrm{nACh}$ receptors, including $\mathrm{AE}$ bicyclic alcohol. These compounds exhibit a voltage-dependent block. ${ }^{18,19}$ In contrast, MLA exerts insurmountable antagonism when preincubated with $\mathrm{ACh}$ at $\alpha 4 \beta 2 \mathrm{nACh}$ receptors but does not display voltage-dependent block, indicating that the insurmountable inhibition was not due to channel blockade but rather differences in the binding kinetics of both the onand off-rates. $^{20}$

To determine whether AE succinimide could bind to the channel lumen, we constructed a current-voltage $(I-V)$ curve where $\mathrm{AE}$ succinimide $(30 \mu \mathrm{M})$ was preincubated for $3 \mathrm{~min}$ and then coapplied with $100 \mu \mathrm{M}$ ACh at different holding potentials ( -90 to $-10 \mathrm{mV}$; Figure 3 ). AE succinimide displayed a stronger inhibition of ACh-induced currents at more negative voltage potentials at $(\alpha 4)_{3}(\beta 2)_{2} \mathrm{nACh}$ receptors (Figure $3 \mathrm{~A}$ ) whereby the percentage block of $\mathrm{ACh}$-induced currents was statistically different between $-50 \mathrm{mV}$ and -90 $\mathrm{mV}$ ( $51 \%$ vs $72 \%$, respectively; Student $t$ test, $p<0.05$ ) (Figure $3 \mathrm{C}$ ). This indicates that the inhibitory effect of $\mathrm{AE}$ 
A

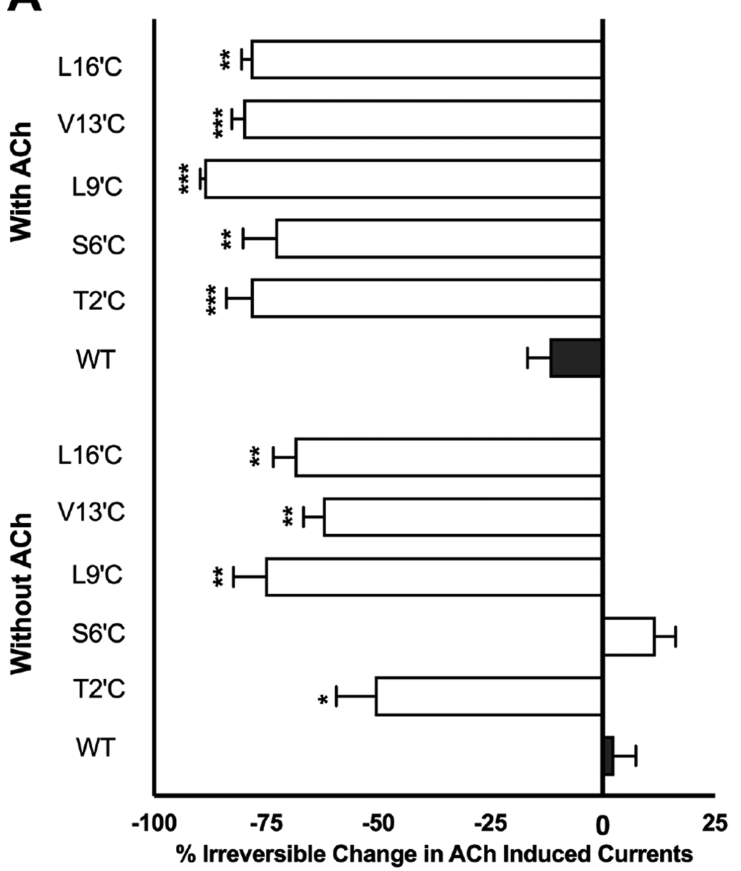

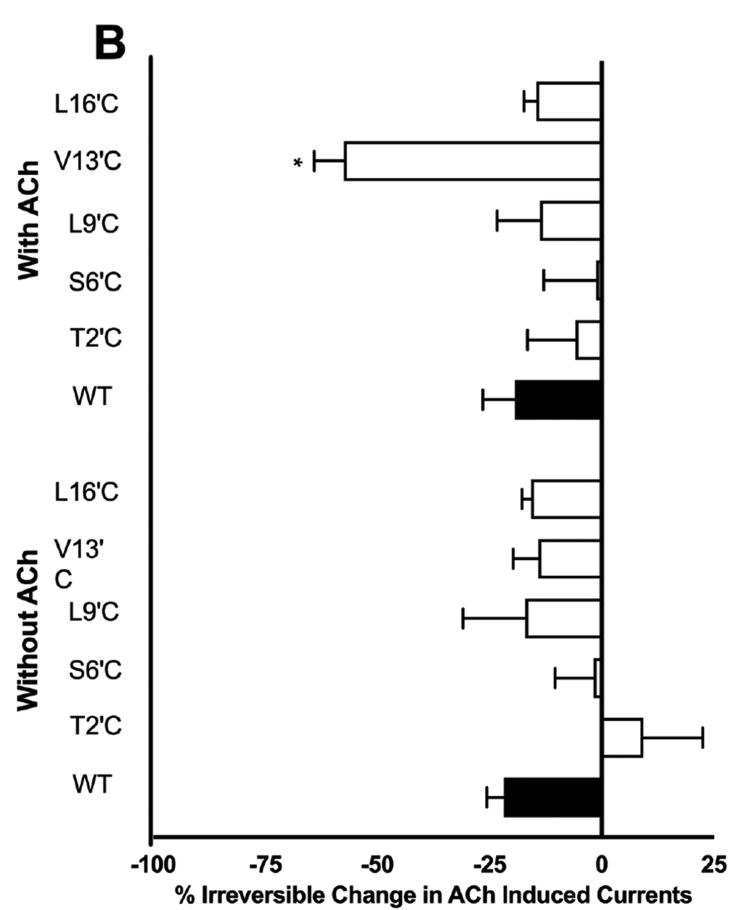

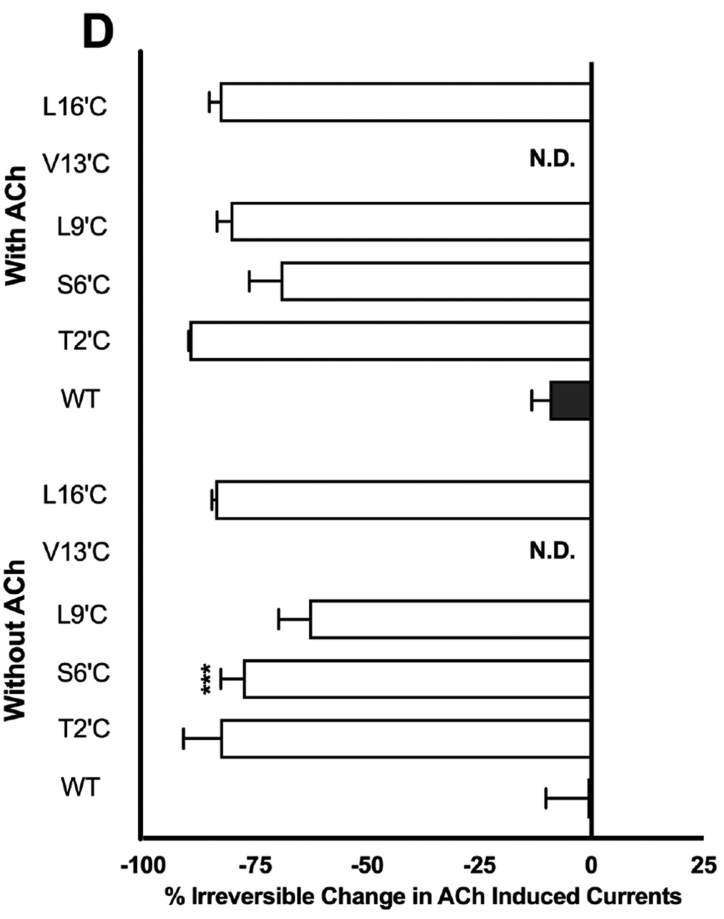

Figure 4. (A) Effects of MTSEA on ACh-induced currents. Bar graph indicates irreversible change in ACh-induced currents after the incubation of either $2.5 \mathrm{mM}$ MTSEA and $1 \mathrm{mM}$ ACh (top half) or $2.5 \mathrm{mM}$ MTSEA alone (bottom half) for 5 min recorded from oocytes injected with 1:1 mRNA ratio $\alpha 4: \beta 2$ of wild-type $\alpha 4, \alpha 4 \mathrm{~T} 2^{\prime} \mathrm{C}, \alpha 4 \mathrm{~S} 6^{\prime} \mathrm{C}, \alpha 4 \mathrm{~L} 9^{\prime} \mathrm{C}, \alpha 4 \mathrm{~V} 13^{\prime} \mathrm{C}$, or $\alpha 4 \mathrm{~L} 16^{\prime} \mathrm{C}$ expressed with wild-type $\beta 2$. Data are mean $\pm \mathrm{SEM}$ from $n$ $=4-8$ oocytes from at least two different batches. Statistical significance is indicated as $* p<0.05$; $* * p<0.01$; ***p<0.001, Student's $t$-test compared to wild-type. (B) Effects of $100 \mu \mathrm{M}$ AE succinimide on ACh-induced currents. Bar graph indicates irreversible change in ACh-induced currents after the incubation of either $100 \mu \mathrm{M} \mathrm{AE}$ succinimide and $1 \mathrm{mM} \mathrm{ACh}$ (top half) or $100 \mu \mathrm{M} \mathrm{AE}$ succinimide (bottom half) for 5 min at wild-type $\alpha 4, \alpha 4 \mathrm{~T} 2^{\prime} \mathrm{C}, \alpha 4 \mathrm{~S} 6^{\prime} \mathrm{C}, \alpha 4 \mathrm{~L} 9^{\prime} \mathrm{C}, \alpha 4 \mathrm{~V} 13^{\prime} \mathrm{C}$, or $\alpha 4 \mathrm{~L} 16^{\prime} \mathrm{C}$ expressed with wild-type $\beta 2$. Data are mean \pm SEM of $n=3-6$ oocytes from at least two different batches. Statistical significance is indicated as $* p<0.05 ; * * p<0.01 ; * * p<0.00$, Student's $t$-test compared to wild-type. (C) Representative trace showing the irreversible effects of $100 \mu \mathrm{M} \mathrm{AE}$ succinimide in the presence of $1 \mathrm{mM}$ ACh on subsequent ACh-induced currents at $\left(\alpha 4 \mathrm{~V} 13^{\prime} \mathrm{C}\right)_{3}(\beta 2)_{2} \mathrm{nAChRs}$. Two pulses of $\mathrm{ACh}(100 \mu \mathrm{M})$ were applied before and after a 5 min incubation with $\mathrm{AE}$ succinimide $(100 \mu \mathrm{M})$ in the presence of $1 \mathrm{mM} \mathrm{ACh}$. The $100 \mu \mathrm{M}$ ACh-induced currents were permanently reduced after a washout time of up to $20 \mathrm{~min}$. (D) Effects of 
Figure 4. continued

competing MTSEA with AE succinimide. Bar graph indicates change in ACh-induced currents after $100 \mu \mathrm{M} \mathrm{AE}$ succinimide was preincubated for 3 min before coapplying $1 \mathrm{mM}$ ACh and $2.5 \mathrm{mM}$ MTSEA for $5 \mathrm{~min}$ (top half) or coapplying with $2.5 \mathrm{mM}$ MTSEA alone without ACh for 5 min (bottom). Data are mean \pm SEM of $n=4-6$ oocytes from at least two different batches. Statistical significance is indicated as $* p<0.05$; $* * p<$ 0.01 ; $* * p<0.001$. Student's $t$-test, no data (N.D.) was obtained for $\alpha 4 \mathrm{~V} 13^{\prime} \mathrm{C}$.

succinimide on $(\alpha 4)_{3}(\beta 2)_{2} \mathrm{nACh}$ receptors is voltage-dependent and suggests that $\mathrm{AE}$ succinimide could also bind close to or within the channel pore of $(\alpha 4)_{3}(\beta 2)_{2} \mathrm{nACh}$ receptors.

We then assessed whether the current-voltage relationship of $\mathrm{AE}$ succinimide at $(\alpha 4)_{2}(\beta 2)_{3}$ receptors is similar to that at the $(\alpha 4)_{3}(\beta 2)_{2}$ receptors. We determined the current-voltage curve with preincubation of $\mathrm{AE}$ succinimide using the same protocol as described for $(\alpha 4)_{3}(\beta 2)_{2}$ receptors (Figure 3B). AE succinimide had similar voltage-dependent effects at $(\alpha 4)_{2}(\beta 2)_{3}$ compared to $(\alpha 4)_{3}(\beta 2)_{2}$ receptors. Thus, AE succinimide also displays stronger inhibition of ACh-induced currents at more negative voltage potentials at $(\alpha 4)_{2}(\beta 2)_{3}$ receptors (Figure 3B). The percentage block of ACh-induced currents was statistically different between $-50 \mathrm{mV}$ and -90 $\mathrm{mV}$ (35\% vs 57\%, respectively; Student $t$ test, $p<0.05$ ) (Figure 3C). We conclude from the current-voltage studies that $\mathrm{AE}$ succinimide can exert its effect by binding within or close to the channel pore in both stoichiometries.

The inhibition by AE succinimide had characteristics distinct from that previously reported for MLA. ${ }^{20}$ While MLA also led to surmountable and insurmountable inhibition at $(\alpha 4)_{3}(\beta 2)_{2}$ $\mathrm{nACh}$ receptors depending on the absence or presence of preincubation, respectively, MLA did not show voltagedependent block. Instead, MLA binds only to the ACh binding sites located at the $\alpha 4-\beta 2$ and $\alpha 4-\alpha 4$ interfaces as demonstrated through covalent trapping of MLA maleimide within the $\alpha 4-\alpha 4$ interface. Thus, the surmountable and insurmountable inhibition arises from different binding kinetics of MLA at the different N-terminal subunit interfaces. Similarly, different binding kinetics could explain the surmountable and insurmountable inhibition of AE succinimide. However, in contrast to MLA, AE succinimide also displays voltage-dependent block with preincubation, indicating an additional distinct binding site for this compound.

AE Succinimide Does Not Bind to TM2 Residues 2'$16^{\prime}$ of the Channel Pore of $\alpha \mathbf{4}$ Subunits. Given that AE succinimide displayed voltage-dependent block, we investigated whether a potential binding site was within the TM2 of $(\alpha 4)_{3}(\beta 2)_{2}$ nACh receptors, as this was previously shown for the AE bicyclic alcohol. ${ }^{19}$ Using a variation on the substituted cysteine accessibility method, we first performed site-directed mutagenesis on amino acids located between $2^{\prime}$ and $16^{\prime}$ known to be accessible to sulfhydryl reagents in the TM2 domain of the $\alpha 4$ subunit as previously reported. ${ }^{22}$ The selected residues, $\mathrm{T} 2$ ' (corresponding to the residue $\mathrm{T} 278$ ), S6' (S282), L9' (L285), V13' (V289), and L16' (L292) of the $\alpha 4$ subunit were each mutated to cysteine. These cysteine mutants were individually coexpressed with wild-type $\beta 2$ subunit mRNA in oocytes, using a 1:1 ratio, and the resultant receptors were assessed using 2-EVC methods. We have previously reported that these mutations do not grossly affect the function of the receptor by performing ACh concentration-response curves when compared to $\alpha 4 \beta 2$ wild-type responses. 19

In order to demonstrate that the cysteine mutants could react with methanethiosulfonate ethylammonium (MTSEA), we applied a high concentration of MTSEA $(2.5 \mathrm{mM})$ for 5 min in the absence or presence of $1 \mathrm{mM}$ ACh at each mutant receptor in order to determine if MTSEA was reacting with the introduced cysteine residue. In both the presence (represented by bars in top half of panel) and absence (represented by bars in bottom half of panel) of ACh, the ACh-evoked currents of $\alpha 4 \mathrm{~T} 2^{\prime} \mathrm{C}, \alpha 4 \mathrm{~L} 9^{\prime} \mathrm{C}, \alpha 4 \mathrm{~V} 13^{\prime} \mathrm{C}$, and $\alpha 4 \mathrm{~L} 16^{\prime} \mathrm{C}$ mutant receptors expressed in the $3: 2$ stoichiometry were significantly reduced compared to wild-type alone, demonstrating that the cysteine residues covalently reacted with MTSEA in all channel states (Figure 4A). In contrast, ACh-evoked currents at the S6 ${ }^{\prime} \mathrm{C}$ mutant receptor were not significantly reduced by MTSEA in the absence of $\mathrm{ACh}$, but in the presence of $\mathrm{ACh}$, currents were significantly reduced, demonstrating that MTSEA does not react at this residue in the closed state but does so in the open state (Figure 4A). This can be explained by the fact that when $\mathrm{ACh}$ binds, it induces a conformational change in the protein that leads to a rotation in the TM2 region exposing the $6^{\prime}$ position. Interestingly, accessibility of the $6^{\prime}$ position can differ between the various Cys-loop channels with the $6^{\prime}$ position being accessible to MTSEA in the closed state in mouse muscle nACh receptors ${ }^{22}$ but not at glycine receptors, ${ }^{23,24}$ which may reflect slight variation in the structure of TM2 in the different receptors. ${ }^{25-27}$

Before competing AE succinimide with MTSEA at each mutated site, we first controlled for whether AE succinimide alone had an effect on the mutant receptors by assessing the effect of $100 \mu \mathrm{M}$ AE succinimide on each mutant, both in the presence (represented by bars in the top half of the panel) and absence (represented by bars in the bottom half of the panel) of coapplied $1 \mathrm{mM}$ ACh (Figure 4B). The $100 \mu \mathrm{M} \mathrm{AE}$ succinimide was not able to irreversibly inhibit $\mathrm{ACh}$-induced currents at wild-type and mutant $\alpha 4 \mathrm{~T} 2^{\prime} \mathrm{C}, \alpha 4 \mathrm{~S} 6^{\prime} \mathrm{C}, \alpha 4 \mathrm{~L} 9^{\prime} \mathrm{C}$, and $\alpha 4 \mathrm{~L} 16^{\prime} \mathrm{C}$ mutant receptors expressed in the $3: 2$ stoichiometry. However, AE succinimide alone irreversibly inhibited subsequent ACh-induced currents on ( $\alpha 4$ $\left.\mathrm{V}_{13} \mathrm{C}\right)_{3}(\beta 2)_{2}$ mutant receptors when applied in the presence of ACh $(57.5 \pm 6.6 \%$; Student's $t$ test, $p<0.05$; Figure $4 \mathrm{C})$ but not in the absence of ACh (Figure 4B). This irreversible inhibition by $\mathrm{AE}$ succinimide in the presence of $\mathrm{ACh}$ at $(\alpha 4$ $\left.\mathrm{V}_{13} \mathrm{C}\right)_{3}(\beta 2)_{2}$ mutant receptors was surprising as, unlike the structurally related thiol-reactive maleimide, ${ }^{28}$ which contains an electrophilic double bond between C3 and C4 that is susceptible to nucleophilic addition by thiols, the succinimide chemical structure is saturated and as such is not expected to display any reactivity with the cysteine mutants as it lacked the critical electrophilic double bond. Further, there is no evidence that cysteines alone can react with the ester moiety.

We then measured the inhibition of ACh-evoked currents after incubation with $\mathrm{AE}$ succinimide for $3 \mathrm{~min}$ before coapplication of AE succinimide and $2.5 \mathrm{mM}$ MTSEA, either in the presence or absence of ACh. Protection from MTSEA modification by AE succinimide was evaluated at each mutated position within the channel pore except for $\alpha 4 \mathrm{~V} 13^{\prime} \mathrm{C}$ mutant receptors as this site caused irreversible inhibition by $\mathrm{AE}$ succinimide in the presence of $\mathrm{ACh}$. Coapplication of $\mathrm{AE}$ 

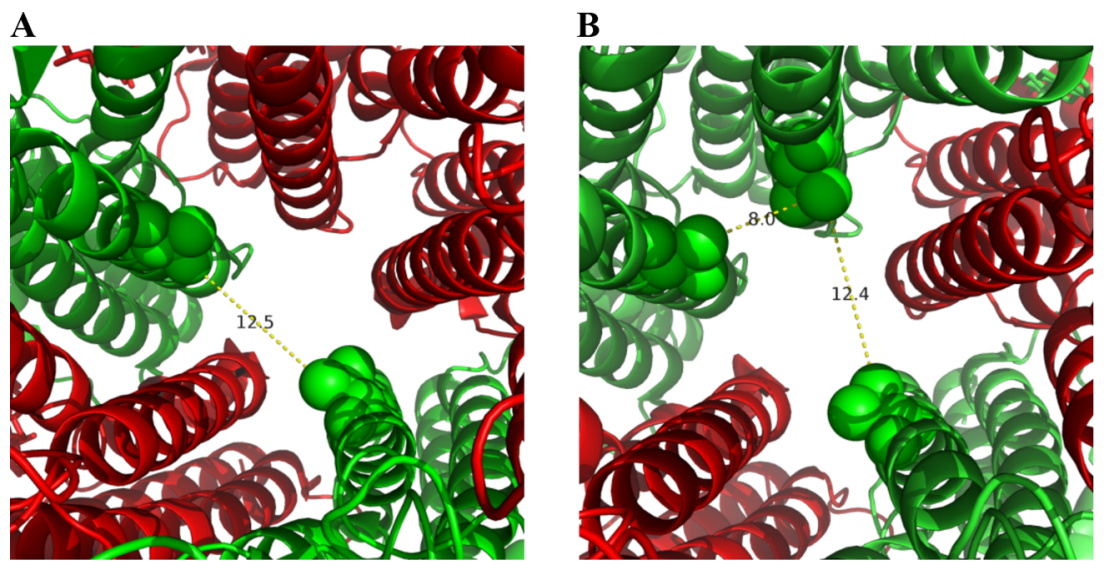

Figure 5. Schematic diagram representing the top view of the channel lumen for $(\mathrm{A})(\alpha 4)_{2}(\beta 2)_{3}$ and $(\mathrm{B})(\alpha 4)_{3}(\beta 2)_{2}$ receptors. Images were generated using PyMol (PDB numbers: $6 \mathrm{cnj}(2: 3)$ and $6 \mathrm{cnk}(3: 2))$ and are based on the Cryo-em structures of human $\alpha 4 \beta 2$ receptor in both stoichiometries. ${ }^{27}$ Green ribbons represent wild-type $\alpha 4$ subunits, and red ribbons represent wild-type $\beta 2$ subunits. The minimum distance between

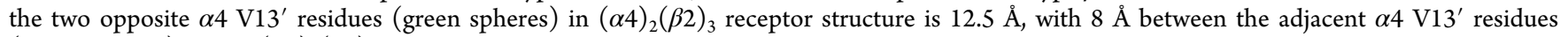
(green spheres) in the $(\alpha 4)_{3}(\beta 2)_{2}$ receptor structure.

succinimide with MTSEA resulted in irreversible inhibition for all mutations tested in the channel pore including the $\mathrm{S}^{\prime} \mathrm{C}$ mutant, which originally did not show irreversible inhibition to MTSEA or AE succinimide alone in the closed state (77.7 \pm 4.9\%; Student's $t$ test, $p<0.001)$.

As none of the $\alpha 4 \mathrm{~T} 2^{\prime} \mathrm{C}, \alpha 4 \mathrm{~S} 6^{\prime} \mathrm{C}, \alpha 4 \mathrm{~L} 9^{\prime} \mathrm{C}$, and $\alpha 4 \mathrm{~L} 16^{\prime} \mathrm{C}$ $(\alpha 4)_{3}(\beta 2)_{2}$ mutant receptors had any significant change in the inhibition by MTSEA when coapplied with AE succinimide, this suggested that $\mathrm{AE}$ succinimide does not directly bind to any of the tested residues in the channel pore (Figure 4D), despite exhibiting voltage-dependent block. Instead, it is proposed that upon binding to an unidentified site possibly near or around the channel lumen, $\mathrm{AE}$ succinimide causes a conformational change to the TM2 domain of the receptor. Indeed, the $\alpha 4 S 6^{\prime} \mathrm{C}$ data shows that accessibility to MTSEA reactivity occurs when AE succinimide is bound (Figure 4D), indicating there are changes in the conformation of the channel pore upon its binding.

AE Succinimide Inhibits $\left(\alpha 4 \mathrm{~V}^{\prime} 3^{\prime} \mathrm{C}\right)_{3}(\beta 2)_{2}$ Receptors by Inducing a Conformational Change to TM2 Detected by Disulfide Cross-Linking. Cysteines on $\alpha 4$ subunits could reside at adjacent or alternate TM2 helices when expressed in the $(\alpha 4)_{3}(\beta 2)_{2}$ stoichiometry. Thus, one hypothesis for the irreversible effects observed with $\mathrm{AE}$ succinimide on $(\alpha 4$ $\left.\mathrm{V} 13^{\prime} \mathrm{C}\right)_{3}(\beta 2)_{2}$ mutant receptors is that $\mathrm{AE}$ succinimide induces a conformational change upon binding, shifting the channel to an irreversible closed state by promoting two $\alpha 4\left(\mathrm{~V} 13^{\prime} \mathrm{C}\right)$ cysteine residues to form a disulfide bond. To test for disulfide bond formation, we first established whether dithiothreitol (DTT), a disulfide-bond reducing agent, could reverse the inhibition. First we determine whether DTT has an effect on its own by preincubating DTT $(1 \mathrm{mM})$ for $5 \mathrm{~min}$ before coapplying DTT with ACh $(300 \mu \mathrm{M})$. DTT had no effect on ACh-evoked currents, indicating DTT does not activate or inhibit the receptor (Figure 6A). This observation is consistent with previous studies on $\mathrm{nACh}$ receptors and DTT where it was shown that $1 \mathrm{mM}$ DTT had no effect on the channel at this concentration. ${ }^{29}$

DTT contains two sulfhydryl moieties and is thus able to reduce disulfide bonds back to a sulfhydryl group via a sequence of thiol-disulfide exchange reactions. Incubating $(\alpha 4$ $\left.\mathrm{V}^{\prime} 3^{\prime} \mathrm{C}\right)_{3}(\beta 2)_{2}$ with $100 \mu \mathrm{M} \mathrm{AE}$ succinimide in the presence of
$1 \mathrm{mM}$ ACh resulted in an irreversible reduction of the ACh current even after a $20 \mathrm{~min}$ wash. Subsequent treatment with 1 $\mathrm{mM}$ DTT restored the same magnitude of ACh evoked currents that were observed prior to $\mathrm{AE}$ succinimide addition (Figure 6A). Thus, the mechanism by which DTT restored $\mathrm{ACh}$ response in our studies is by reducing the disulfide bond that forms when two adjacent or alternate $\alpha 4 \mathrm{~V} 13^{\prime} \mathrm{C}$ residues react.

In order to determine which cysteine residues are reacting, we first assessed the distance between the cysteines that are adjacent, i.e. at $\alpha 4\left(\mathrm{~V} 13^{\prime} \mathrm{C}\right)-\alpha 4\left(\mathrm{~V} 13^{\prime} \mathrm{C}\right)$ and at alternating $\alpha 4\left(\mathrm{~V} 13^{\prime} \mathrm{C}\right)-\beta 2-\alpha 4\left({\left.\mathrm{~V} 13^{\prime} \mathrm{C}\right)}^{\prime}\right.$ subunit arrangements in $(\alpha 4$ $\left.\mathrm{V} 13^{\prime} \mathrm{C}\right)_{2}(\beta 2)_{3}$ and $\left(\alpha 4 \mathrm{~V} 13^{\prime} \mathrm{C}\right)_{3}(\beta 2)_{2}$ receptors (Figure 5). We found that the cysteines were spatially closer if they were in the adjacent subunit, i.e., $\alpha 4\left(\mathrm{~V} 13^{\prime} \mathrm{C}\right)-\alpha 4\left(\mathrm{~V} 13^{\prime} \mathrm{C}\right)$ (approximately $8 \AA$ ), than if the cysteines were alternating, i.e. $\alpha 4\left(\mathrm{~V} 13^{\prime} \mathrm{C}\right)-\beta 2-\alpha 4\left(\mathrm{~V} 13^{\prime} \mathrm{C}\right)$ (approximately $12.5 \AA$ ). Therefore, conformational changes induced by $\mathrm{AE}$ succinimide could be more likely to promote disulfide bond formation where adjacent $13^{\prime}$ cysteines were present in close proximity to each other, irreversibly blocking the channel in the $(\alpha 4)_{3}(\beta 2)_{2}$ stoichiometry only.

In order to establish whether alternating $\alpha 4$ $\left(\mathrm{V} 13^{\prime} \mathrm{C}\right)-\beta 2-\alpha 4\left(\mathrm{~V}^{\prime} 3^{\prime} \mathrm{C}\right)$ cysteines were reacting, we expressed the $\alpha 4 \mathrm{~V} 13^{\prime} \mathrm{C}$ mutation in the 2:3 stoichiometry, $(\alpha 4$ $\left.\mathrm{V}^{\prime} 3^{\prime} \mathrm{C}\right)_{2}(\beta 2)_{3}$, eliminating the possibility of disulfide bond formation between adjacent $\alpha 4$ subunits. The effects of 100 $\mu \mathrm{M}$ AE succinimide alone were evaluated at wild-type

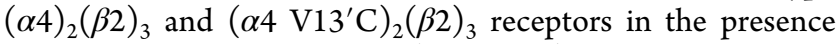
and absence of $100 \mu \mathrm{M}$ ACh (Figure $6 \mathrm{~B}$ ). An example of the experimental protocol used is shown in Figure 6C. The 100 $\mu \mathrm{M}$ AE succinimide was not able to irreversibly inhibit AChinduced currents at wild type $(\alpha 4)_{2}(\beta 2)_{3}$ and $(\alpha 4$ $\left.\mathrm{V} 13^{\prime} \mathrm{C}\right)_{2}(\beta 2)_{3}$ receptors in the presence or absence of ACh. This demonstrates that introduced cysteines at $\alpha 4$ subunits that alternate with $\beta 2$ subunits $\left[\alpha 4\left(\mathrm{~V} 13^{\prime} \mathrm{C}\right)-\beta 2-\alpha 4\left(\mathrm{~V} 13^{\prime} \mathrm{C}\right)\right]$ do not form disulfide bonds, inferring that only adjacent cysteines are able to generate a disulfide bond in the presence of $\mathrm{AE}$ succinimide and $\mathrm{ACh}$. The requirement of both $\mathrm{ACh}$ and $\mathrm{AE}$ succinimide to be bound when the disulfide bonds are created suggests that either $\mathrm{AE}$ succinimide binds in a different orientation or position when $\mathrm{ACh}$ is bound, or the presence of 
A

$1 \mathrm{mM}$ DTT

$1 \mathrm{mM} \mathrm{ACh}$

$100 \mu \mathrm{M}$ AE Succ

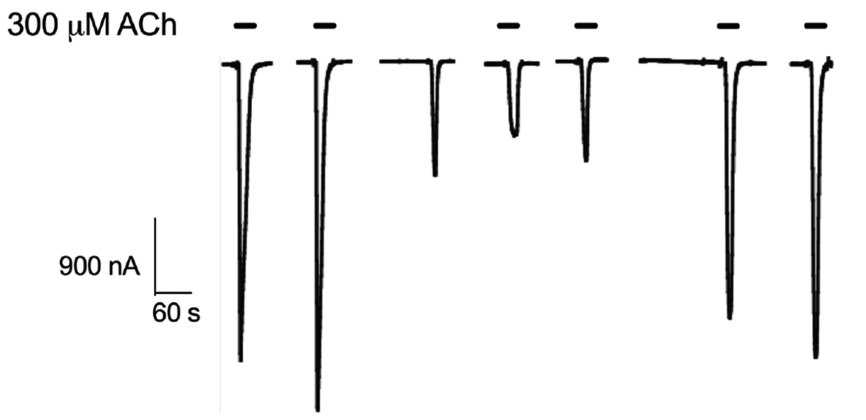

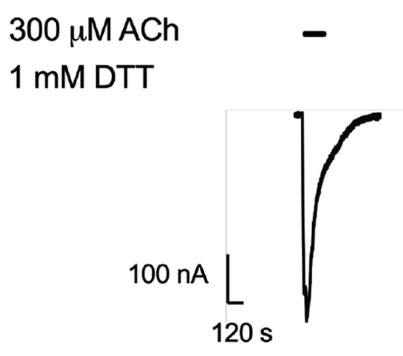

C

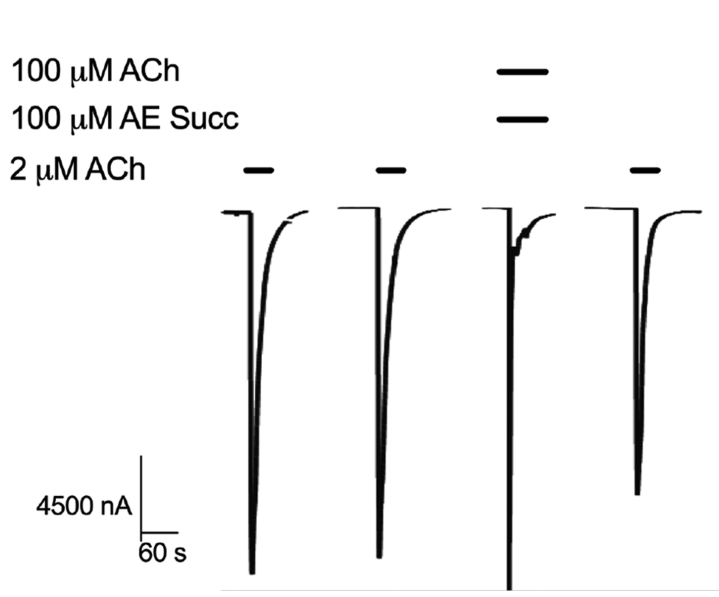

B

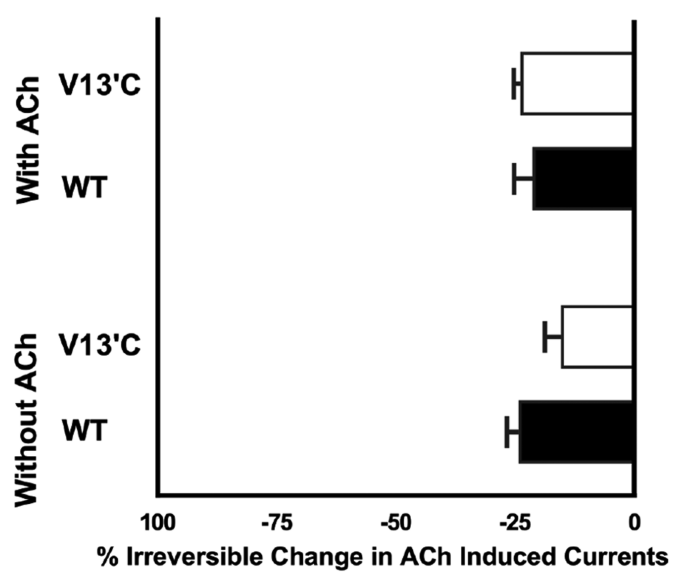

D

Figure 6. (A) Representative trace showing recovery of ACh-induced currents on $\left(\alpha 4 \mathrm{~V} 13^{\prime} \mathrm{C}\right)_{3}(\beta 2)_{2} \mathrm{nACh}$ receptors after treatment with $1 \mathrm{mM}$

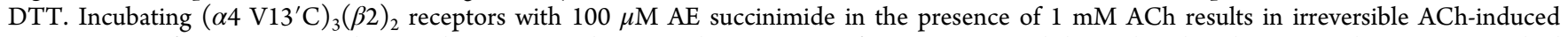
currents even after a $20 \mathrm{~min}$ washout. Subsequent incubation with $1 \mathrm{mM}$ DTT for $5 \mathrm{~min}$ restored the ACh-induced current. The $1 \mathrm{mM}$ DTT had no effect on ACh $(300 \mu \mathrm{M})$ even when preincubated for $5 \mathrm{~min}$. (B) Effects of $100 \mu \mathrm{M}$ AE succinimide alone on ACh-induced currents at $(\alpha 4$ $\left.\mathrm{V} 13^{\prime} \mathrm{C}\right)_{2}(\beta 2)_{3}$ receptors. Bar graph indicates irreversible change in ACh-induced currents after incubating with either $100 \mu \mathrm{M}$ AE succinimide in the presence of $100 \mu \mathrm{M}$ ACh (top half) or $100 \mu \mathrm{M} \mathrm{AE}$ succinimide alone for 5 min (bottom half). Data were recorded from oocytes injected with 1:10 mRNA ratio $\alpha 4: \beta 2$ of $\alpha 4$ or $\alpha 4 \mathrm{~V} 13^{\prime} \mathrm{C}$ to wild-type $\beta 2$. Data are mean \pm SEM of $n=4$ oocytes from at least two different batches. (C) Representative trace showing the reversible effects of $100 \mu \mathrm{M} \mathrm{AE}$ succinimide on subsequent ACh-induced currents on $\left(\alpha 4 \mathrm{~V} 13^{\prime} \mathrm{C}\right)_{2}(\beta 2)_{3} \mathrm{nAChRs}$. Two pulses of ACh $(2 \mu \mathrm{M})$ were applied before and after a $5 \mathrm{~min}$ incubation with $\mathrm{AE}$ succinimide $(100 \mu \mathrm{M})$ in the presence of $100 \mu \mathrm{M}$ ACh. (D) Representative trace showing recovery of ACh-induced currents on $\left(\alpha 4 \mathrm{~V}_{13} \mathrm{C}_{3}\right)_{3}(\beta 2)_{2} \mathrm{nAChRs}$ after treatment with $1 \mathrm{mM} \mathrm{AE}$ bicyclic alcohol.

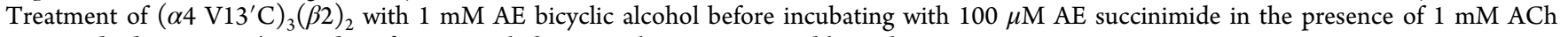
protected adjacent $\mathrm{V} 13^{\prime} \mathrm{C}$ residues from cross-linking, resulting in recoverable ACh currents.

AE succinimide distorts the conformational changes induced by $\mathrm{ACh}$ such that the $\mathrm{V} 13^{\prime} \mathrm{C}$ residues are close enough to cross-link.

We finally sought to assess whether AE bicyclic alcohol, a structurally related compound previously demonstrated to bind to the $\alpha 4 \mathrm{~V} 13^{\prime} \mathrm{C}$ position, could inhibit the reaction between the adjacent cysteines. ${ }^{19}$ Therefore, in a separate experiment, 1 $\mathrm{mM}$ AE bicyclic alcohol was applied at $\alpha 4\left(\mathrm{~V}_{13}{ }^{\prime} \mathrm{C}\right)_{3}(\beta 2)_{2}$ receptors before coapplying with $\mathrm{AE}$ bicyclic alcohol, 100 $\mu \mathrm{M}$ AE succinimide, and $1 \mathrm{mM}$ ACh. Subsequent AChcurrents were not significantly different from ACh-currents determined before applying AE succinimide (Student $t$ test $p=$ 
$0.35, p>0.05$ ) (Figure $6 \mathrm{D}$ ), suggesting that $\mathrm{AE}$ bicyclic

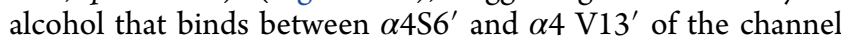

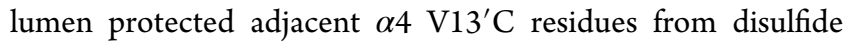
bond formation. ${ }^{19}$

\section{CONCLUSIONS}

In this study, we found that $\mathrm{AE}$ succinimide inhibits AChactivated currents at $\alpha 4 \beta 2 \mathrm{nACh}$ receptors at both stoichiometries. The inhibition by $\mathrm{AE}$ succinimide occurs via two different mechanisms: direct competitive antagonism with ACh when the compound is not preincubated and an apparent insurmountable mechanism when the compound is preincubated. Current-voltage relationship studies indicated that the binding site for AE succinimide could be within the TM2 domain, but substituted-cysteine accessibility suggested this was not occurring between $2^{\prime}$ and $16^{\prime}$. Further, we demonstrated that upon binding, $\mathrm{AE}$ succinimide induced a conformational change to the TM2 domain as detected by using the $\left(\alpha 4 \mathrm{~V} 13^{\prime} \mathrm{C}\right)_{3}(\beta 2)_{2} \mathrm{nACh}$ receptor. With this mutated receptor, we showed that adjacent cysteines at $\alpha 4\left(\mathrm{~V} 13^{\prime} \mathrm{C}\right)$ reacted to form a disulfide bond that caused persistent inhibition when both $\mathrm{ACh}$ and $\mathrm{AE}$ succinimide were bound and that this could be recovered by treatment with the disulfide reducing agent DTT. This is unusual as most inhibitors act to either block the pore or compete with the orthosteric ligand, ACh.

When comparing the parent antagonist MLA, which is highly potent and binds to the interface of $\alpha 4-\beta 2$ and $\alpha 4-\alpha 4$ subunits with its analogues, $\mathrm{AE}$ bicyclic alcohol and $\mathrm{AE}$ succinimide, it is clear that chemical modification not only significantly affected the binding affinity but also demonstrated that such ligands bind to alternative binding sites to inhibit ACh. These differences may be the result of the size of the compounds. Indeed, AE succinimide is much larger than $\mathrm{AE}$ bicyclic alcohol because of the additional anthranilatesuccinimide ester moiety and thus could be binding higher in the channel, closer to the extracellular compartment, as this part of the channel is larger and can accommodate the anthranilate-succinimide ester moiety, or in surrounding transmembrane areas. Having differently sized molecules binding to different areas of the TM2 domain is consistent with the proposal that the channel is more constricted at the $\mathrm{L9}^{\prime} \mathrm{C}$ position ${ }^{26,27,30}$ where smaller molecules such as $\mathrm{AE}$ bicyclic alcohol can be accommodated. In contrast, $\mathrm{AE}$ succinimide is smaller than MLA and thus can bind further down toward the pore in comparison to MLA or in surrounding transmembrane regions.

Finally, the findings reported in this study have implications for the kinetics and potency of drug action, and the approaches used, in particular the cysteine cross-linking experiments, are an elegant way of interrogating novel ligand binding sites. Future studies will aim to identify the binding site of $\mathrm{AE}$ succinimide.

\section{METHODS}

$\mathrm{AE}$ succinimide and $\mathrm{AE}$ bicyclic alcohol were synthesized as previously described. ${ }^{17,18} \mathrm{ACh}$, dithiothreitol (DTT), gentamycin, methanethiosulfonate ethylammonium (MTSEA), sodium pyruvate, theophylline, tricaine, and 4-(2-hydroxyethyl)-1-piperazineethanesulfonic acid (HEPES) were obtained from Sigma-Aldrich (Australia).

Mutagenesis and Transcription of $\alpha 4 \beta 2$ Receptors. The cDNA encoding wild-type rat $\alpha 4 \mathrm{nACh}$ receptor subunit subcloned into the pSP64 and the $\beta 2$ subunit subcloned into the pSP65 were generous gifts from Professor Jim Boulter (University of California, Los Angeles, CA).

Mutagenesis and transcription of $\alpha 4 \beta 2 \mathrm{nACh}$ receptors were performed as previously described. ${ }^{19}$ In brief, cysteine mutations were generated within the channel pore of the $\alpha 4 \mathrm{nACh}$ receptor subunit by using sense and antisense oligonucleotide primers and the QuickChange II Site-directed Mutagenesis kit protocol (Stratagene, La Jolla, CA). The design of the primers incorporated a series of silent mutations that allowed for quick screening of colonies. Single colonies of $E$. coli containing plasmid DNA were isolated, grown, and DNApurified using the Wizard Plus Minipreps DNA Purification System (Promega, New South Wales, Australia). Mutants were screened by restriction enzyme analysis and then confirmed by full DNA sequencing.

Plasmids containing wild-type and mutant $\alpha 4$ subunits were linearized with EcoRI. Wild-type $\beta 2$ was linearized with HindIII. $\alpha 4$ and $\beta 2$ mRNAs were synthesized using the SP6 mMESSAGE Mmachine transcription kit (Ambion Inc., Austin, TX). RNA was treated with DNase before purification, and RNA concentrations were measured by spectrophotometry using a Nanodrop instrument (Thermo Fisher Scientific). To express the two stoichiometries, mRNA of wild-type $\alpha 4$ or mutant $\alpha 4$ were mixed with wild-type $\beta 2$ subunits in either a 1:4 or 1:10 $\alpha 4: \beta 2$ ratio to obtain the $(\alpha 4)_{2}(\beta 2)_{3}$ stoichiometry or either a $1: 1$ or $10: 1 \quad \alpha 4: \beta 2$ ratio to obtain the $(\alpha 4)_{3}(\beta 2)_{2}$ stoichiometry. $^{20}$

Xenopus laevis Surgery, Oocyte Extraction, and Injection. Oocytes from Xenopus laevis were surgically removed while under general anesthetic using tricaine $(850 \mathrm{mg} / 500 \mathrm{~mL}$ supplemented with $\left.\mathrm{Na}_{2} \mathrm{CO}_{3}(0.6 \mathrm{mg} / 500 \mathrm{~mL})\right)$ in accordance with the Animal Ethics Guidelines approved by the University of Sydney (Reference number: 2013/5915).

Harvested lobes of oocytes were manually cut into small clusters of cells (5-10 oocytes), rinsed with oocyte-releasing buffer 2 (OR2) $\left(82.5 \mathrm{mM} \mathrm{NaCl}, 2 \mathrm{mM} \mathrm{KCl}, 1 \mathrm{mM} \mathrm{MgCl}{ }_{2}, 5 \mathrm{mM}\right.$ HEPES (hemi- $\mathrm{Na}^{+}$ salt); $\mathrm{pH} 7.5)$, and digested with collagenase $\mathrm{A}(2 \mathrm{mg} / \mathrm{mL}$ in OR2) for $1.5 \mathrm{~h}$ at room temperature to release and defolliculate the individual oocytes. The oocytes were further washed with OR2 and ND96 wash solution $(96 \mathrm{mM} \mathrm{NaCl}, 2 \mathrm{mM} \mathrm{KCl}, 1 \mathrm{mM} \mathrm{MgCl} 2,1.8$ $\mathrm{mM} \mathrm{CaCl} 2,5 \mathrm{mM}$ HEPES (hemi-Na ${ }^{+}$salt), supplemented with 2.5 $\mathrm{mM}$ pyruvate, and $0.5 \mathrm{mM}$ theophylline; $\mathrm{pH} 7.4$ ). Healthy stage VVI oocytes were selected for use and kept in ND96 wash solution at 4 ${ }^{\circ} \mathrm{C}$. When digested, oocytes were microinjected with $25 \mathrm{ng}$ of mRNA per cell using the required mRNA ratio. After injection, the oocytes were kept for $3-5$ days at $18{ }^{\circ} \mathrm{C}$ in the presence of ND96 wash solution supplemented with $50 \mu \mathrm{g} / \mathrm{mL}$ gentamycin.

Electrophysiological Recordings. Two-electrode voltage-clamp recordings were performed as previously described. ${ }^{20}$ Briefly, oocytes expressing wild-type $\alpha 4 \beta 2$ and mutant $\alpha 4 \beta 2 \mathrm{nACh}$ receptors were clamped at $-60 \mathrm{mV}$ using a GeneClamp 500B amplifier together with a Powerlab/200 (AD Instruments, Sydney, Australia) and Chart Version 3.5 for PC and continually perfused with $\mathrm{Ca}^{2+}$ free solution where $\mathrm{Ca}^{2+}$ is replaced with $\mathrm{Ba}^{2+}$ to maintain buffer osmolarity (115 $\mathrm{mM} \mathrm{NaCl}, 2.5 \mathrm{mM} \mathrm{KCl}, 1.8 \mathrm{mM} \mathrm{BaCl}, 10 \mathrm{mM}$ HEPES; $\mathrm{pH} 7.4)$. The recording microelectrodes $(0.2-1.1 \mathrm{M} \Omega)$ were generated from capillary glass (Harvard Apparatus, Holliston, MA) using a singlestage glass microelectrode puller (Narishige, Tokyo, Japan) and were filled with $3 \mathrm{M} \mathrm{KCl}$. Compounds were stored at $-20^{\circ} \mathrm{C}$ and made up to the required concentrations in $\mathrm{Ca}^{2+}$-free solution before applying to the oocyte by gravity flow at a rate of $5 \mathrm{~mL} / \mathrm{min}$.

ACh Concentration-Response Curves. Concentration-response curves for ACh were constructed from the peak current response obtained from a range of concentrations $(0.1 \mu \mathrm{M}-10 \mathrm{mM})$ and normalized to the maximal ACh-elicited current $\left(I / I_{\text {Max }}\right)$. To allow the receptor to recover from the desensitized state, oocytes were washed for $10 \mathrm{~min}$ between $\mathrm{ACh}$ applications. To determine the mode of inhibition by $\mathrm{AE}$ succinimide, ACh concentration-response curves were determined in the presence of a fixed concentration of $\mathrm{AE}$ succinimide. Where curves were determined with a preincubation, $\mathrm{AE}$ succinimide was applied for $3 \mathrm{~min}$ before the solution was switched to contain the same concentration of $\mathrm{AE}$ succinimide with ACh. 
Inhibitory Concentration-Response Curves. Inhibition concentration response curves for $\mathrm{AE}$ succinimide were constructed by applying increasing $\mathrm{AE}$ succinimide concentrations $(0.03 \mu \mathrm{M}$ to 1 $\mathrm{mM})$ in the presence of $100 \mu \mathrm{M} \mathrm{ACh}$ at $(\alpha 4)_{3}(\beta 2)_{2} \mathrm{nACh}$ receptors. Peak responses were normalized to the responses to the $\mathrm{ACh} \mathrm{EC}_{50}$ $(100 \mu \mathrm{M})\left(I / I_{50}\right)$.

For the $(\alpha 4)_{2}(\beta 2)_{3} \mathrm{nACh}$ receptors, inhibitory concentrationresponse curves of the $\mathrm{AE}$ succinimide were constructed using increasing $\mathrm{AE}$ succinimide concentrations $(0.03-300 \mu \mathrm{M})$ in the presence of $100 \mu \mathrm{M}$ ACh. Peak responses were normalized to the responses of ACh $I_{\mathrm{Max}}$ current $(100 \mu \mathrm{M})\left(I / I_{\mathrm{Max}}\right)$. Where the curve was determined with preincubation, $\mathrm{AE}$ succinimide was applied for 3 min before the solution was switched to contain the same concentration of $\mathrm{AE}$ succinimide with $\mathrm{ACh}$.

Voltage-Dependent Block. Voltage-dependent block of $\mathrm{AE}$ succinimide at $(\alpha 4)_{3}(\beta 2)_{2}$ and $(\alpha 4)_{2}(\beta 2)_{3}$ receptors was investigated by measuring currents induced by $\mathrm{ACh}$ in $10 \mathrm{mV}$ steps at a membrane potential range of 0 to $-90 \mathrm{mV}$. Currents induced by (i) $100 \mu \mathrm{M}$ ACh alone and (ii) $100 \mu \mathrm{M}$ ACh in the presence of $\mathrm{AE}$ succinimide $(30 \mu \mathrm{M})$ were measured. To compare between different oocytes, all $\mathrm{ACh}$-induced currents were normalized by the current induced by 100 $\mu \mathrm{M}$ ACh at $-90 \mathrm{mV}$.

Substituted Cysteine Accessibility Studies. Stock solutions of methanethiosulfonate ethylammonium (1 M; MTSEA) were made up in distilled water, aliquoted, and stored at $-20{ }^{\circ} \mathrm{C}$. For each application, the solution was thawed, diluted to the working concentration in $\mathrm{Ca}^{2+}$ free solution, and used immediately.

The effects of $2.5 \mathrm{mM}$ MTSEA and AE succinimide $(100 \mu \mathrm{M})$ on ACh-induced currents at wild-type $(\alpha 4)_{3}(\beta 2)_{2}$ and mutant $(\alpha 4)_{3}(\beta 2)_{2} \mathrm{nACh}$ receptors were assayed by measuring the baseline average of the peak currents evoked by two applications of $100 \mu \mathrm{M}$ ACh before incubating with either MTSEA or AE succinimide in $\mathrm{Ca}^{2+}$ free solution for $5 \mathrm{~min}$. This was followed by measuring the average of two peak currents evoked by two applications of $100 \mu \mathrm{M}$ ACh. The effects of either $2.5 \mathrm{mM}$ MTSEA or AE succinimide $(100 \mu \mathrm{M})$ were assayed either in the presence or absence of $1 \mathrm{mM} \mathrm{ACh}$.

A similar assay was used to evaluate the effects of $\mathrm{AE}$ succinimide $(100 \mu \mathrm{M})$ on ACh-induced currents at $(\alpha 4)_{2}(\beta 2)_{3}$ and $(\alpha 4$ $\left.\mathrm{V}_{13}^{\prime} \mathrm{C}\right)_{2}(\beta 2)_{3} \mathrm{nACh}$ receptors ACh-induced currents. The baseline average of two peak currents evoked by two applications of $2 \mu \mathrm{M} \mathrm{ACh}$ were measured before incubating with $\mathrm{AE}$ succinimide in $\mathrm{Ca}^{2+}$ free solution for $5 \mathrm{~min}$. This was followed by measuring the average of two peak currents evoked by two applications of $2 \mu \mathrm{M}$ ACh. The effect of AE succinimide $(100 \mu \mathrm{M})$ was measured either in the presence or absence of $100 \mu \mathrm{M}$ ACh.

To investigate the ability of $\mathrm{AE}$ succinimide to protect the cysteine mutant from sulfyhydryl modification, $100 \mu \mathrm{M}$ AE succinimide was incubated for $3 \mathrm{~min}$ to allow it to occupy its binding site before adding MTSEA to the perfusion system for a further $5 \mathrm{~min}$ in either the open or closed channel states.

The ability of $1 \mathrm{mM} \mathrm{AE}$ bicyclic alcohol to compete with $\mathrm{AE}$ succinimide at $\alpha 4\left(\mathrm{~V}_{13}{ }^{\prime} \mathrm{C}\right)_{3}(\beta 2)_{2}$ was assayed by measuring the baseline average of two peak currents evoked by two applications of $100 \mu \mathrm{M}$ ACh before incubating $1 \mathrm{mM}$ AE bicyclic alcohol in $\mathrm{Ca}^{2+}$ free solution for $3 \mathrm{~min}$ before coapplying the $1 \mathrm{mM} \mathrm{AE}$ bicyclic alcohol, $100 \mu \mathrm{M} \mathrm{AE}$ succinimide, and $1 \mathrm{mM} \mathrm{ACh}$. This was followed by measuring the average of two peak currents evoked by two applications of $100 \mu \mathrm{M}$ ACh.

DTT $(1 \mathrm{mM})$ was either preincubated alone before coapplication with $300 \mu \mathrm{M}$ ACh or used in reducing studies with $100 \mu \mathrm{M} \mathrm{AE}$ succinimide at $\alpha 4\left(\mathrm{~V} 13^{\prime} \mathrm{C}\right)_{3}(\beta 2)_{2}$ by measuring the baseline average of two peak currents evoked by two applications of $300 \mu \mathrm{M} \mathrm{ACh}$ before incubating $100 \mu \mathrm{M} \mathrm{AE}$ succinimide in $\mathrm{Ca}^{2+}$ free solution for 3 min and subsequently coapplying the $100 \mu \mathrm{M} \mathrm{AE}$ succinimide with 1 $\mathrm{mM} \mathrm{ACh}$.

Data Analysis. The amplitude of each current response to ACh (I) was normalized to the amplitude of the maximum current response to $\mathrm{ACh}\left(I_{\mathrm{Max}}\right)\left(I / I_{\mathrm{Max}}\right.$ unless otherwise stated). Normalized concentration-response curves were constructed and analyzed using GraphPad Prism7 and fitted according to the Hill equation:

$$
I=I_{\max } \frac{[\mathrm{A}]^{n_{\mathrm{H}}}}{[\mathrm{A}]^{n_{\mathrm{H}}}+\mathrm{EC}_{50}{ }^{n_{\mathrm{H}}}}
$$

where $[\mathrm{A}]$ is the ligand concentration and $n_{\mathrm{H}}$ is the Hill slope. From this equation, the concentration of the agonist that activates $50 \%$ of expressed receptors $\left(\mathrm{EC}_{50}\right)$ or in the case of inhibitory concentration response curves, the concentration of the antagonist that inhibits $50 \%$ of the evoked $\mathrm{ACh}$ current $\left(\mathrm{IC}_{50}\right)$ were calculated. Data are presented as mean \pm SEM obtained from a minimum of 3 oocytes over a minimum of 2 batches. The $95 \%$ confidence interval or mean \pm SEM derived from the curve fitting is provided.

Peak current values from the individual concentration-response curves were analyzed using one-way ANOVA with Tukey's posthoc test. For all other statistical analyses the differences between groups were calculated using an unpaired Student's $t$ test unless otherwise stated. A p-value $<0.05$ was determined to be statistically significant.

To compare the $\log \mathrm{IC}_{50}$ for individual curves for the inhibitory dose response curves at $(\alpha 4)_{2}(\beta 2)_{3}$ receptors, the max was constrained to be one and the bottom was constrained to be zero, and an unpaired Student's $t$ test was conducted. The effect of a compound was taken as $\left.I-\left(I_{\mathrm{ACh}(\mathrm{After}}\right)-I_{\mathrm{ACh}(\mathrm{Before})}\right)$, and statistical significance was performed using the Student's $t$-test.

Biphasic concentration-response curves were fitted with a twocomponent Hill equation, using GraphPad Prism 7, as defined below:

$$
I=I_{\max }\left[\frac{[\mathrm{A}] \text { Frac1 }}{[\mathrm{A}]+\mathrm{EC}_{50}(1)}+\frac{[\mathrm{A}] \text { Frac2 }}{[\mathrm{A}]+\mathrm{EC}_{50}(2)}\right]
$$

where Frac1 and Frac2 are the fractions of high- and low-sensitivity components of the concentration-response curves with halfmaximum responses $\mathrm{EC}_{50}(1)$ and $\mathrm{EC}_{50}(2)$, respectively. In this analysis, the Hill slope was constrained to 1 . Values derived from the biphasic curvefit were obtained from the curve of best-fit, and either the mean \pm SEM or the $95 \%$ confidence intervals are provided. To establish whether a concentration-response curve was better approximated by a monophasic or a biphasic curve, an F-test was performed on the curvefit results using GraphPad Prism 7 where the threshold for significance is $p<0.05$. This is based on the premise that if the relative increase in the sum of squares of the monophasic model (compared to the biphasic model) is greater than the relative increase in the degrees of freedom, then the biphasic model provides a better fit to the data.

For the effects of MTSEA or AE succinimide on cysteine mutants, statistical significance was evaluated by comparing to wild-type receptors. For investigating the ability of $\mathrm{AE}$ succinimide in protecting the cysteine mutant from sulfyhydryl modification, statistical significance was taken by comparison to the corresponding effects of MTSEA in the same mutant.

\section{AUTHOR INFORMATION}

\section{Corresponding Author}

Mary Chebib - School of Pharmacy, Faculty of Medicine and Health, Sydney, The University of Sydney;

(1) orcid.org/0000-0001-6204-3178;

Email: mary.collins@sydney.edu.au

\section{Other Authors}

Taima Qudah - School of Pharmacy, Faculty of Medicine and Health, Sydney, The University of Sydney

Gracia X. Quek - School of Pharmacy, Faculty of Medicine and Health, Sydney, The University of Sydney

Dinesh Indurthi - School of Pharmacy, Faculty of Medicine and Health, Sydney, The University of Sydney

Nasiara Karim - School of Pharmacy, Faculty of Medicine and Health, Sydney, The University of Sydney

Jill I. Halliday - The Australian National University, Canberra, Australia 
Nathan Absalom - School of Pharmacy, Faculty of Medicine and Health, Sydney, The University of Sydney

Malcolm D. McLeod - The Australian National University, Canberra, Australia; \orcid.org/00000002-2343-3226

Complete contact information is available at: https://pubs.acs.org/10.1021/acschemneuro.9b00525

\section{Author Contributions}

N.A., M.D.M., and M.C. conceived and designed the method. T.Q., G.X.Q., N.K., D.I., and J.I.H. conducted the experiments. T.Q., G.X.Q., N.A., M.D.M., and M.C. wrote the manuscript.

\section{Funding}

This research was supported by a Project (APP1069417) from the Australian National Health and Medical Research Council (M.D.M. and M.C.) and by a Discovery Project (DP0986469) from the Australian Research Council (M.D.M. and M.C.). T.Q., G.Q., J.I.H. were supported by Australian Postgraduate Award. D.I. was supported by International Postgraduate Research Scholarship, and T.Q., G.X.Q., J.I.H., and D.I. were also supported by the John A. Lamberton scholarship.

Notes

The authors declare no competing financial interest.

\section{ABBREVIATIONS}

HEPES, 4-(2-hydroxyethyl)-1-piperazineethanesulfonic acid; DTT, dithiothreitol; LGIC, ligand-gated ion channel; MTSEA, methanethiosulfonate ethylammonium; MLA, methyllycaconitine; $(\mathrm{nACh})$ receptor, nicotinic acetylcholine; NCA, noncompetitive antagonist; SCAM, substituted cysteine accessibility method

\section{REFERENCES}

(1) Bertrand, D., and Terry, A. V., Jr (2018) The wonderland of neuronal nicotinic acetylcholine receptors. Biochem. Pharmacol. 151, 214-225.

(2) Giastas, P., Zouridakis, M., and Tzartos, S. J. (2018) Understanding structure-function relationships of the human neuronal acetylcholine receptor: insights from the first crystal structures of neuronal subunits. Br. J. Pharmacol. 175 (11), 1880-1891.

(3) Karlin, A. (2002) Emerging structure of the nicotinic acetylcholine receptors. Nat. Rev. Neurosci. 3 (2), 102-14.

(4) Gotti, C., and Clementi, F. (2004) Neuronal nicotinic receptors: from structure to pathology. Prog. Neurobiol. (Oxford, U. K.) 74 (6), 363-96.

(5) Arias, H. R., Bhumireddy, P., and Bouzat, C. (2006) Molecular mechanisms and binding site locations for noncompetitive antagonists of nicotinic acetylcholine receptors. Int. J. Biochem. Cell Biol. 38 (8), 1254-76.

(6) Yu, Y., Shi, L., and Karlin, A. (2003) Structural effects of quinacrine binding in the open channel of the acetylcholine receptor. Proc. Natl. Acad. Sci. U. S. A. 100 (7), 3907-12.

(7) Chiara, D. C., Hamouda, A. K., Ziebell, M. R., Mejia, L. A., Garcia, G., 3rd, and Cohen, J. B. (2009) [(3)H]chlorpromazine photolabeling of the torpedo nicotinic acetylcholine receptor identifies two state-dependent binding sites in the ion channel. Biochemistry 48 (42), 10066-77.

(8) Chiara, D. C., Hong, F. H., Arevalo, E., Husain, S. S., Miller, K. W., Forman, S. A., and Cohen, J. B. (2009) Time-resolved photolabeling of the nicotinic acetylcholine receptor by $[3 \mathrm{H}]$ azietomidate, an open-state inhibitor. Mol. Pharmacol. 75 (5), 1084-95.

(9) Moroni, M., Vijayan, R., Carbone, A., Zwart, R., Biggin, P. C., and Bermudez, I. (2008) Non-agonist-binding subunit interfaces confer distinct functional signatures to the alternate stoichiometries of the alpha 4 beta 2 nicotinic receptor: An alpha 4-alpha 4 interface is required for Zn2+ potentiation. J. Neurosci. 28 (27), 6884-6894.

(10) Moroni, M., Zwart, R., Sher, E., Cassels, B. K., and Bermudez, I. (2006) alpha 4 beta 2 nicotinic receptors with high and low acetylcholine sensitivity: Pharmacology, stoichiometry, and sensitivity to long-term exposure to nicotine. Mol. Pharmacol. 70 (2), 755-768.

(11) Zwart, R., Carbone, A. L., Moroni, M., Bermudez, I., Mogg, A. J., Folly, E. A., Broad, L. M., Williams, A. C., Zhang, D., Ding, C., Heinz, B. A., and Sher, E. (2008) Sazetidine-A is a potent and selective agonist at native and recombinant alpha 4 beta 2 nicotinic acetylcholine receptors. Mol. Pharmacol. 73 (6), 1838-43.

(12) Carbone, A. L., Moroni, M., Groot-Kormelink, P. J., and Bermudez, I. (2009) Pentameric concatenated (alpha 4)(2)(beta 2) (3) and (alpha 4)(3)(beta 2)(2) nicotinic acetylcholine receptors: subunit arrangement determines functional expression. Br. J. Pharmacol. 156 (6), 970-981.

(13) Harpsoe, K., Ahring, P. K., Christensen, J. K., Jensen, M. L., Peters, D., and Balle, T. (2011) Unraveling the High- and LowSensitivity Agonist Responses of Nicotinic Acetylcholine Receptors. J. Neurosci. 31 (30), 10759-10766.

(14) Mazzaferro, S., Benallegue, N., Carbone, A., Gasparri, F., Vijayan, R., Biggin, P. C., Moroni, M., and Bermudez, I. (2011) Additional acetylcholine (ACh) binding site at alpha4/alpha4 interface of (alpha4beta2)2alpha4 nicotinic receptor influences agonist sensitivity. J. Biol. Chem. 286 (35), 31043-54.

(15) Ward, J. M., Cockcroft, V. B., Lunt, G. G., Smillie, F. S., and Wonnacott, S. (1990) Methyllycaconitine: a selective probe for neuronal alpha-bungarotoxin binding sites. FEBS Lett. 270 (1-2), $45-8$.

(16) Palma, E., Bertrand, S., Binzoni, T., and Bertrand, D. (1996) Neuronal nicotinic alpha 7 receptor expressed in Xenopus oocytes presents five putative binding sites for methyllycaconitine. J. Physiol. 491 (1), 151-161.

(17) Barker, D., Brimble, M. A., McLeod, M. D., and Savage, G. P. (2004) Synthesis of tricyclic analogues of methyllycaconitine using ring closing metathesis to append a $\mathrm{B}$ ring to an $\mathrm{AE}$ azabicyclic fragment. Org. Biomol. Chem. 2 (11), 1659-69.

(18) Barker, D., Lin, D. H., Carland, J. E., Chu, C. P., Chebib, M., Brimble, M. A., Savage, G. P., and McLeod, M. D. (2005) Methyllycaconitine analogues have mixed antagonist effects at nicotinic acetylcholine receptors. Bioorg. Med. Chem. 13 (14), $4565-75$.

(19) Quek, G. X., Lin, D., Halliday, J. I., Absalom, N., Ambrus, J. I., Thompson, A. J., Lochner, M., Lummis, S. C., McLeod, M. D., and Chebib, M. (2010) Identifying the binding site of novel methyllycaconitine (MLA) analogs at $\alpha 4 \beta 2$ nicotinic acetylcholine receptors. ACS Chem. Neurosci. 1 (12), 796-809.

(20) Absalom, N. L., Quek, G., Lewis, T. M., Qudah, T., von Arenstorff, I., Ambrus, J. I., Harpsøe, K., Karim, N., Balle, T., McLeod, M. D., and Chebib, M. (2013) Covalent trapping of methyllycaconitine at the alpha4-alpha4 interface of the alpha4beta2 nicotinic acetylcholine receptor: antagonist binding site and mode of receptor inhibition revealed. J. Biol. Chem. 288 (37), 26521-26532.

(21) Francis, M. M., Choi, K. I., Horenstein, B. A., and Papke, R. L. (1998) Sensitivity to voltage-independent inhibition determined by pore-lining region of the acetylcholine receptor. Biophys. J. 74 (5), 2306-17.

(22) Akabas, M. H., Kaufmann, C., Archdeacon, P., and Karlin, A. (1994) Identification of acetylcholine receptor channel-lining residues in the entire M2 segment of the alpha subunit. Neuron 13 (4), 91927.

(23) Shan, Q., Haddrill, J. L., and Lynch, J. W. (2002) Comparative surface accessibility of a pore-lining threonine residue $\left(\mathrm{T} 6^{\prime}\right)$ in the glycine and GABA(A) receptors. J. Biol. Chem. 277 (47), 44845-53.

(24) Absalom, N. L., Schofield, P. R., and Lewis, T. M. (2009) Pore structure of the Cys-loop ligand-gated ion channels. Neurochem. Res. 34 (10), 1805-15. 
(25) Du, J., Lu, W., Wu, S., Cheng, Y., and Gouaux, E. (2015) Glycine receptor mechanism elucidated by electron cryo-microscopy. Nature 526 (7572), 224-9.

(26) Morales-Perez, C. L., Noviello, C. M., and Hibbs, R. E. (2016) $\mathrm{X}$-ray structure of the human alpha4beta2 nicotinic receptor. Nature 538 (7625), 411-415.

(27) Walsh, R. M., Jr, Roh, S. H., Gharpure, A., Morales-Perez, C. L., Teng, J., and Hibbs, R. E. (2018) Structural principles of distinct assemblies of the human alpha4beta2 nicotinic receptor. Nature 557 (7704), 261-265.

(28) Ambrus, J. I., Halliday, J. I., Kanizaj, N., Absalom, N., Harpsøe, K., Balle, T., Chebib, M., and McLeod, M. D. (2012) Covalent attachment of antagonists to the alpha7 nicotinic acetylcholine receptor: synthesis and reactivity of substituted maleimides. Chem. Commun. (Cambridge, U. K.) 48 (53), 6699-6701.

(29) McLaughlin, J. T., Hawrot, E., and Yellen, G. (1995) Covalent modification of engineered cysteines in the nicotinic acetylcholine receptor agonist-binding domain inhibits receptor activation. Biochem. J. 310 (3), 765-769.

(30) Unwin, N. (2005) Refined structure of the nicotinic acetylcholine receptor at 4 angstrom resolution. J. Mol. Biol. 346 (4), 967-989. 